\title{
Ni Oxidation State and Ligand Saturation Impact on the Capability of Octaazamacrocyclic Complexes to Bind and Reduce $\mathrm{CO}_{2}$
}

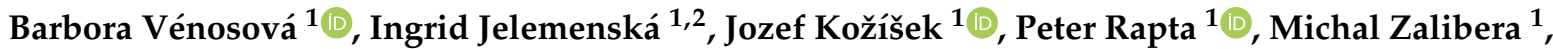 \\ Michal Novotný ${ }^{3}$, Vladimir B. Arion ${ }^{4} \mathbb{D}$ and Lukáš Bučinský ${ }^{1, *}$
}

1 Faculty of Chemical and Food Technology, Institute of Physical Chemistry and Chemical Physics, Slovak University of Technology in Bratislava, Radlinského 9, 81237 Bratislava, Slovakia; barbora.venosova@stuba.sk (B.V.); ingrid.jelemenska@stuba.sk (I.J.); jozef.kozisek@stuba.sk (J.K.); peter.rapta@stuba.sk (P.R.); michal.zalibera@stuba.sk (M.Z.)

2 Department of Chemistry, Faculty of Natural Sciences, Constantine the Philosopher University in Nitra, 94974 Nitra, Slovakia

3 Department of Physics, Faculty of Science, University of Ostrava, 30. dubna 22, 70103 Ostrava, Czech Republic; michal.novotny@osu.cz

4 Institute of Inorganic Chemistry, University of Vienna, Währinger Strasse 42, 1090 Vienna, Austria; vladimir.arion@univie.ac.at

* Correspondence: lukas.bucinsky@stuba.sk

Citation: Vénosová, B.; Jelemenská, I.; Kožíšek, J.; Rapta, P.; Zalibera, M.; Novotný, M.; Arion, V.B.; Bučinský, L. Ni Oxidation State and Ligand Saturation Impact on the Capability of Octaazamacrocyclic Complexes to Bind and Reduce $\mathrm{CO}_{2}$. Molecules 2021 26, 4139. https://doi.org/10.3390/ molecules26144139

Academic Editors: Miroslav Kohout, Carlo Gatti, David L. Cooper and Maxim L. Kuznetsov

Received: 27 May 2021

Accepted: 1 July 2021

Published: 7 July 2021

Publisher's Note: MDPI stays neutral with regard to jurisdictional claims in published maps and institutional affiliations.

Copyright: (c) 2021 by the authors. Licensee MDPI, Basel, Switzerland. This article is an open access article distributed under the terms and conditions of the Creative Commons Attribution (CC BY) license (https:/ / creativecommons.org/licenses/by/ $4.0 /)$.

\begin{abstract}
Two 15-membered octaazamacrocyclic nickel(II) complexes are investigated by theoretical methods to shed light on their affinity forwards binding and reducing $\mathrm{CO}_{2}$. In the first complex ${ }^{1}\left[\mathrm{Ni}^{\mathrm{II}} \mathbf{L}\right]^{0}$, the octaazamacrocyclic ligand is grossly unsaturated ( $\pi$-conjugated), while in the second ${ }^{1}\left[\mathrm{Ni}^{\mathrm{II}} \mathbf{L H}\right]^{2+}$ one, the macrocycle is saturated with hydrogens. One and two-electron reductions are described using Mulliken population analysis, quantum theory of atoms in molecules, localized orbitals, and domain averaged fermi holes, including the characterization of the $\mathrm{Ni}-\mathrm{C}_{\mathrm{CO} 2}$ bond and the oxidation state of the central $\mathrm{Ni}$ atom. It was found that in the [NiLH] complex, the central atom is reduced to $\mathrm{Ni}^{0}$ and/or $\mathrm{Ni}^{\mathrm{I}}$ and is thus able to bind $\mathrm{CO}_{2}$ via a single $\sigma$ bond. In addition, the two-electron reduced ${ }^{3}[\mathrm{NiL}]^{2-}$ species also shows an affinity forwards $\mathrm{CO}_{2}$.
\end{abstract}

Keywords: DFT; nickel complexes; $\mathrm{CO}_{2}$ reduction; $\mathrm{CO}_{2}$ fixation; $\mathrm{CO}_{2}$ catalysis; domain averaged fermi holes; bonding analysis; QTAIM; MPA

\section{Introduction}

The catalytic reduction of carbon dioxide to $\mathrm{C} 1$ chemicals (or even to liquid fuels, e.g., methanol) is receiving considerable attention. Lowering the concentration of atmospheric $\mathrm{CO}_{2}$ and/or the control of the amount of $\mathrm{CO}_{2}$ exhausts into the atmosphere is nowadays one of the crucial challenges in the fight against the dramatic climate changes due to global warming. Several recent reviews describe the electrocatalytic and/or photocatalytic reduction of $\mathrm{CO}_{2}$ using different molecular catalytic systems [1-7]. Many of these utilize expensive $4 \mathrm{~d}$ and $5 \mathrm{~d}$ transition metals, such as $\mathrm{Ru}, \mathrm{Rh}, \mathrm{Pd}, \mathrm{Re}, \mathrm{Os}$, or Ir with bipyridine [8-10] or phosphate-like ligands [11-14]. In addition, mononuclear 3d transition metal ( $\mathrm{Fe}, \mathrm{Ni}, \mathrm{Co}$ ) complexes with macrocyclic ligands have been reported to be active in the reduction of $\mathrm{CO}_{2}$ [4,15-20], as well as multinuclear $3 \mathrm{~d}$ transition metal $(\mathrm{Fe}, \mathrm{Ni}, \mathrm{Cu})$ complexes [21-26], as summarized in several recent reviews [1,2,5,7]. As a further instance, binuclear $\mathrm{Cu}(\mathrm{II})$ tetraazacyclotetradecane units show affinity forwards carboxylates, which could be a further interesting option for a $\mathrm{CO}_{2}$ reduction strategy [27-31].

It is generally assumed that the affinity of transition metal complexes towards $\mathrm{CO}_{2}$, and their ability to reduce it, is closely related to a low oxidation state of the central metal atom, as found in $\mathrm{Fe}(0)$-porphyrins [4], $\mathrm{Co}(\mathrm{I})$ and $\mathrm{Ni}(\mathrm{I})$ complexes of 1,4,8,11tetraazacyclotetradecane (denoted as cyclam) [16,17,32,33], or Co(I) and Fe(I) corroles [20,34]. 
Several cyclam complexes of $\mathrm{Co}(\mathrm{I}, \mathrm{II})$ [35-43] and $\mathrm{Ni}(\mathrm{I}, \mathrm{II})$ [44-49] have already been extensively studied, concerning their potential in electrochemical or photochemical reduction of $\mathrm{CO}_{2}[1,2,5,7]$. Wang et al. [5] summarize the electrocatalytic potentials of $\mathrm{CO}_{2}$ reduction with different $\mathrm{Ni}$ complexes, the $\mathrm{CO}_{2}$ to $\mathrm{CO}$ conversion potential of, e.g., [Ni(cyclam)] ${ }^{2+}$ is $-1.0 \mathrm{~V}\left(\mathrm{H}_{2} \mathrm{O}\right.$ at $\mathrm{pH} 4.1$ with a $\mathrm{Hg}$ working electrode $)$ as found by Sauvage et al. [17], later also confirmed by Froehlich and Kubiak [49] using a glassy carbon electrode (-1.3 V). The lowest potential with respect to $\mathrm{CO}_{2}$ to $\mathrm{CO}$ conversion pointed out in Wang et al. [5] was achieved with the phosphine dinuclear complex $\left[\mathrm{Ni}_{2}\left(\mathrm{l}-\mathrm{CNCH}_{3}\right)\left(\mathrm{CNCH}_{3}\right) 2\right.$ (12-dppm)2] $(\mathrm{dppm}=$ bis(diphenylphosphino)methane) that could catalyse the electro-reduction of liquid $\mathrm{CO}_{2}$ to $\mathrm{CO}$ at approximately $-0.63 \mathrm{~V}$ vs. NHE [21], although a further catalytic reaction was hindered due to the capture of the evolved $\mathrm{CO}$ by the dinuclear nickel complex [5]. Despite the extensive experimental research in the field, the insight into their electronic structure and the understanding of the interaction between the central metal atom and the carbon atom of $\mathrm{CO}_{2}$ remains relatively limited. The ability of certain macrocyclic complexes to bind $\mathrm{CO}_{2}$, in contrast to other quite similar structures, which do not show $\mathrm{CO}_{2}$ affinity, has not yet been sufficiently addressed by theoretical methods. Among the few reports published so far, Sakaki [50,51] studied the affinity of $\mathrm{Ni}(\mathrm{I}, \mathrm{II})$ complexes for $\mathrm{CO}_{2}$ with different combinations of $\mathrm{NH}_{3}$ and $\mathrm{F}^{-}$ligands. Besides, several studies focused on the frontier orbitals features between the central metal atom and the $\mathrm{CO}_{2}$ carbon, to characterize their interaction, including calculations of relevant properties such as electronic transitions [2]. Aside from the oxidation state of the central metal atom, several other experimental studies have considered the impact of $\pi$-conjugation of the macrocycle, the presence of an apical co-ligand, and solvent effects on the ability to bind and/or reduce $\mathrm{CO}_{2}$ [46-48].

Herein, we focus on the analysis of the relation between the electronic structure of 15-membered octaazamacrocyclic nickel complexes and their affinity for $\mathrm{CO}_{2}$. We have chosen the simplest nickel(II) complex from a previously reported series (originally denoted $\left[\mathbf{N i L}^{\mathbf{1}}\right]$, herein abbreviated [NiL], see Figure 1a) [52,53], as our trial complex with an almost completely unsaturated ( $\pi$-conjugated) macrocycle. The conjugation is interrupted by an $\mathrm{sp}^{3}$ hybridized methylene group carbon in the 15-membered chelate ring. Interestingly, the hydrogens of the $\mathrm{sp}^{3}$-hybridized carbon in [NiL] were found to be acidic [52,53]. [NiL] does not show any affinity forwards $\mathrm{CO}_{2}$ upon reduction (vide infra). In contrast, the hydrogenated (fully saturated) analogue (denoted as [NiLH], see Figure $1 \mathrm{~b})$, which is similar to the $[\mathrm{Ni}(\text { cyclam })]^{2+}[2,49,50,54-56]$, is capable of binding $\mathrm{CO}_{2}$ upon reduction. The energetics and optimal geometries of the studied [NiL] and [NiLH] compounds (including the $\mathrm{CO}_{2}$ adducts) are compiled in the first two results sections. Afterwards, the Mulliken population analysis (MPA), i.e., the atomic charges and atomic populations, and the quantum theory of atoms in molecules (QTAIM) analysis are utilized to characterize the oxidation state and bonding in the studied complexes. In the last section, theoretical insights into the electronic structure of starting nickel complexes and their $\mathrm{CO}_{2}$ adducts is offered from the perspective of localized orbitals, domain averaged fermi holes $(\mathrm{DAFH})$, and frontier orbitals.

This paper is dedicated to prof. Linus Pauling as a part of the Special Issue in his honour. We try to communicate the insights into chemical bonding from the perspective of the different approaches ubiquitous in computational chemistry. Aside from the orbital picture, we explore the common features of distinct theoretical methods and seek the complementarity in diversity, as well as their direct comparison, in the characterization of the bonding interactions in the studied complexes. We particularly focus on the oxidation state of the central $\mathrm{Ni}$ atom and the $\mathrm{N}-\mathrm{C}_{\mathrm{CO} 2}$ bond. 


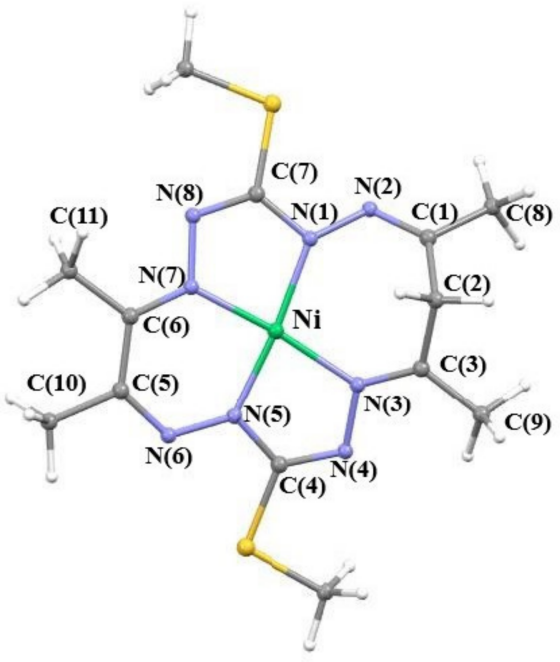

(a)

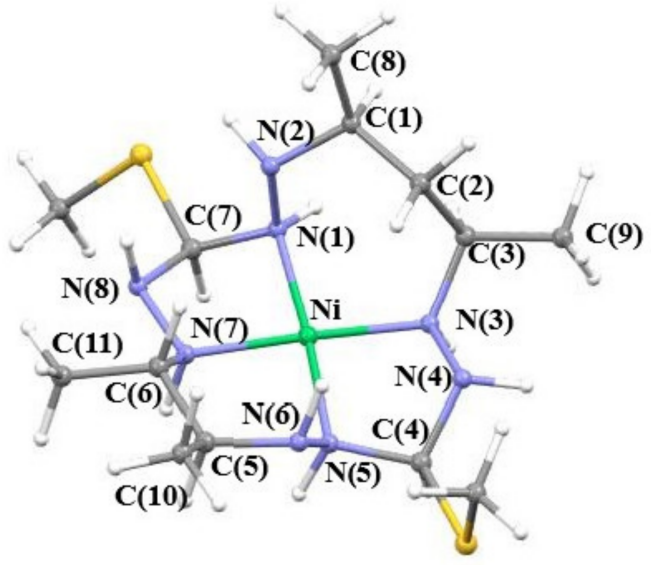

(b)

Figure 1. Optimized molecular structures of (a) ${ }^{1}[\mathrm{NiL}]^{0}$ and (b) ${ }^{1}[\mathrm{NiLH}]^{2+}$ complexes with atom labelling.

\section{Results}

\subsection{Energetics}

Total energies and enthalpies of studied compounds ([NiL] and [NiLH]) are compiled in Table S1, including the energetics of their optimized geometries with $\mathrm{CO}_{2}$ and the free $\mathrm{CO}_{2}$ molecule itself. To further distinguish and characterize the complexes studied, the following notation is applied where appropriate: e.g. ${ }^{2}\left[\mathbf{N i}^{\mathrm{I}} \mathbf{L H}\right]^{+}$denotes the $[\mathbf{N i L H}]$ species in a doublet spin state, $\mathrm{Ni}$ in oxidation state I and a total charge of +1 . The B3LYP/6$311 G^{*}$ reaction energy $(E)$ and enthalpy $(H)$ were evaluated in the following manner:

$$
\begin{gathered}
\Delta E_{R}=E_{\mathrm{NiCO}_{2}}-\left(E_{\mathrm{Ni}}+E_{\mathrm{CO}_{2}}\right) \\
\Delta H_{R}=\mathrm{H}_{\mathrm{NiCO}_{2}}-\left(\mathrm{H}_{\mathrm{Ni}}+\mathrm{H}_{\mathrm{CO}_{2}}\right) \\
\Delta E_{I}=E_{\mathrm{NiCO}_{2}}-\left(E_{\mathrm{CO}_{2}}^{\mathrm{NiCO}_{2}}+E_{\mathrm{Ni}}^{\mathrm{NiCO}_{2}}\right)
\end{gathered}
$$

where subscript $R$ denotes reaction energy/enthalpy and subscript $I$ denotes interaction energy. The optimized structure of a given complex is denoted as $\mathrm{Ni}$, the complex with $\mathrm{CO}_{2}$ is denoted as $\mathrm{NiCO}_{2}$, and the free carbon dioxide is denoted as $\mathrm{CO}_{2}$ in Equations (1) and (2). In Equation (3), the molecular fragments are denoted as $\mathrm{NiCO}_{2}$ and $\mathrm{NiCO}_{2}$ and represent the geometry of $\mathrm{CO}_{2}$ and the $\mathrm{Ni}$ complexes in the particular $\mathrm{NiCO}_{2}$ complex, respectively.

The BSSE uncorrected reaction and interaction $E$ and $H$ values for all the studied species, as well as the counterpoise corrected (CPC) interaction energy $\triangle E_{I}^{C P C}$ and the distances between $\mathrm{Ni}$ and the carbon of $\mathrm{CO}_{2}\left(\mathrm{Ni}-\mathrm{C}_{\mathrm{CO}}\right)$ are collected in Table 1. According to the B3LYP / 6-311G $\mathrm{G}^{*}$ calculations, the reduced species ${ }^{1}\left[\mathrm{Ni}^{0} \mathbf{L H}\right]^{0}$ binds $\mathrm{CO}_{2}$ in the ground state (see Table 1 and Figure $2 \mathrm{~d}$ ) as well as in the ${ }^{2}\left[\mathbf{N i}^{\mathbf{I}} \mathbf{L H}\right]^{+}$state, as found previously for similar aliphatic $\mathrm{Ni}^{\mathrm{I}}$ complexes [49]. In addition, the reduced species ${ }^{3}[\mathrm{NiL}]^{2-}$ is also able to bind $\mathrm{CO}_{2}$ (see Table 1 and Figure 2c) although the triplet state is above the singlet ground state, hence it has to be considered as an excited state (see Table S1). The remaining species do not show the ability to bind $\mathrm{CO}_{2}$, i.e., the $\mathrm{Ni}-\mathrm{C}_{\mathrm{CO} 2}$ distances found are above $3.5 \AA$ and the BSSE uncorrected interaction energies do not exceed $-8 \mathrm{~kJ} \mathrm{~mol}^{-1}$. According to the calculated energetics, the ${ }^{1}\left[\mathbf{N i}^{0} \mathbf{L H}\right]^{0}$ complex shows a considerably larger affinity to $\mathrm{CO}_{2}$ compared to ${ }^{3}[\mathbf{N i L}]^{2-}$ and ${ }^{2}[\mathbf{N i L H}]^{+}$, which is true for both $\Delta E_{\mathrm{I}}$ and $\Delta E_{\mathrm{R}}$ (see Table 1 ), with the $\mathrm{CO}_{2}$ molecule being the most bent in ${ }^{1}\left[\mathbf{N i}^{0} \mathbf{L H}\right]^{0}$ (see Table S2). Even though the values obtained with the CPC approach are higher, the conclusions remain the same. Furthermore, 
it should be noted that when using the CPC approach the solvent effect is not accounted for. For ${ }^{2}[\mathrm{NiLH}]^{+}$, the interaction energy indicates that $\mathrm{CO}_{2}$ binding with this complex is weaker than with ${ }^{3}[\mathrm{NiL}]^{2-}$ and ${ }^{1}[\mathrm{NiLH}]^{0}$. The small negative ${ }^{2}[\mathrm{NiLH}]^{+}$reaction energy $\Delta E_{\mathrm{R}}$ suggests only a lightly exothermic process, whereas for the other two complexes ${ }^{3}[\mathrm{NiL}]^{2-}$ and ${ }^{1}[\mathrm{NiLH}]^{0}$ the binding of $\mathrm{CO}_{2}$ is considerably more exothermic (see Table 1 ). It is pertinent to note that in the calculations of molecular complexes, especially with smaller basis sets as is the case herein, the BSSE plays an important role when deciding about the strength of the interaction. This error can be considerable and lead to overestimated interaction energies $\left(\approx 108 \mathrm{~kJ} / \mathrm{mol}\right.$ in the case of ${ }^{1}\left[\mathrm{Ni}^{0} \mathbf{L H}\right]^{0}$ or $40 \mathrm{~kJ} / \mathrm{mol}$ in the case of $\left.{ }^{2}[\mathrm{NiLH}]^{+}\right)$.

Due to the predicted affinity of ${ }^{1}[\mathrm{NiLH}]^{0},{ }^{2}[\mathrm{NiLH}]^{+}$, and ${ }^{3}[\mathrm{NiL}]^{2-}$ for binding $\mathrm{CO}_{2}$, these complexes (including their $\mathrm{CO}_{2}$ adducts ${ }^{1}\left[\mathrm{NiLH}-\mathrm{CO}_{2}\right]^{0},{ }^{2}\left[\mathrm{NiLH}-\mathrm{CO}_{2}\right]^{+}$, and ${ }^{3}[\mathrm{NiL}-$ $\left.\mathrm{CO}_{2}\right]^{2-}$ ) will be used as the reference compounds in our endeavour to identify the characteristics of the electronic structure that promotes a high affinity forward $\mathrm{CO}_{2}$. This analysis will be further extended by comparison with chosen [NiL] complexes to examine in further detail their failure to bind $\mathrm{CO}_{2}$, namely ${ }^{1}\left[\mathrm{NiL}-\mathrm{CO}_{2}\right]^{0}$ and ${ }^{1}\left[\mathrm{NiL}_{\mathrm{fr}} \mathrm{CO}_{2}\right]^{0}$. The complex ${ }^{1}\left[\mathrm{NiL}-\mathrm{CO}_{2}\right]^{0}$ represents the optimized geometry, with $\mathrm{d}\left(\mathrm{Ni}-\mathrm{C}_{\mathrm{CO} 2}\right)$ being equal to $3.576 \AA$, i.e., no Ni-C $\mathrm{C}_{\mathrm{CO} 2}$ bond (see Table 1 ). For the geometry optimization of ${ }^{1}$ [NiL$\left.{ }_{\text {fr }} \mathrm{CO}_{2}\right]^{0}$ the $\mathrm{d}\left(\mathrm{Ni}-\mathrm{C}_{\mathrm{CO} 2}\right)$ distance has been frozen at $1.913 \AA$ as found in ${ }^{1}\left[\mathrm{NiLH}-\mathrm{CO}_{2}\right]^{0}$, so as to simulate an artificially constrained system and to observe the resulting effect on the electronic structure.

\subsection{Optimized Geometries}

Bond distances and bond angles of chosen B3LYP/6-311G* optimized complexes are summarized in Table S2a,b. The studied [NiL] complexes contain a 15-membered octaazamacrocyclic ligand with one $\mathrm{sp}^{3}$-hybridized carbon atom in the macrocycle, which leads to a non-planar geometry (see Figure 1). Optimized structures of all species derived from the [NiL] complexes show only a small deviation from planarity in the $\mathrm{NiN}_{4}$ coordination polyhedron, angles $\mathrm{NiN}(1) \mathrm{N}(2)$ and $\mathrm{NiN}(5) \mathrm{N}(6)$ are between $132-133^{\circ}$ and $131-132^{\circ}$, respectively. However, a significant distortion from the planar geometry can be seen when saturating the macrocyclic ligand with hydrogen atoms (i.e., for complex ${ }^{1}[\mathrm{NiLH}]^{2+}$, see Figure 1) which also leads to the out of the plane displacement of the N(2) atom $\left(\mathrm{NiN}(1) \mathrm{N}(2)=110.77^{\circ}\right)$. In general, when comparing [NiLH] to the [NiL] complexes, a slight elongation of the N-N bond lengths in [NiLH] can be observed, as well as further bending within the coordination polyhedron (see Table S2a,b). Furthermore, in the case of the ${ }^{1}[\mathrm{NiLH}]^{0}$ complex, we observe that the $\mathrm{Ni}-\mathrm{N}(1)$ and $\mathrm{Ni}-\mathrm{N}(5)$ distances become grossly elongated in comparison to those in ${ }^{1}[\mathrm{NiLH}]^{2+}$. Hence, the coordination polyhedron in ${ }^{1}[\mathrm{NiLH}]^{0}$ is considerably distorted from a square-planar geometry.

Table 1. The reaction and interaction energies/enthalpies of the studied $[\mathrm{NiL}]$ and $[\mathrm{NiLH}]$ complexes with $\mathrm{CO}_{2}$ in different spin states, including $\mathrm{Ni}-\mathrm{C}_{\mathrm{CO} 2}$ bond lengths.

\begin{tabular}{|c|c|c|c|c|c|}
\hline & $\begin{array}{c}\Delta E_{\mathrm{R}} \\
{\left[\mathrm{kJ} \mathrm{mol} \mathrm{mol}^{-1}\right]}\end{array}$ & $\begin{array}{c}\Delta E_{\mathrm{I}} \\
{\left[\mathrm{kJ} \mathrm{mol}^{-1}\right]}\end{array}$ & $\begin{array}{c}\Delta E_{\mathrm{I}}^{\mathrm{CPC}} \\
{\left[\mathrm{kJ} \mathrm{mol}^{-1}\right]}\end{array}$ & $\begin{array}{c}\Delta H_{\mathrm{R}} \\
{\left[\mathrm{kJ} \mathrm{mol}^{-1}\right]}\end{array}$ & $\begin{array}{c}\mathrm{d}\left(\mathrm{Ni}-\mathrm{C}_{\mathrm{CO} 2}\right) \\
[\AA]]\end{array}$ \\
\hline${ }^{3}[\mathrm{NiL}]^{2-}$ & -27.16 & -210.59 & -159.49 & -88.13 & 2.051 \\
\hline${ }^{1}[\mathrm{NiL}]^{2-}$ & -7.70 & & & -1.28 & 3.689 \\
\hline${ }^{2}[\mathrm{NiL}]^{-}$ & -5.27 & & & -1.55 & 3.511 \\
\hline${ }^{1}[\mathrm{NiL}]^{0}$ & -4.37 & -11.08 & 1.21 & -0.33 & 3.576 \\
\hline${ }^{2}[\mathrm{NiL}]^{+}$ & -2.68 & & & -1.11 & 3.603 \\
\hline${ }^{1}[\mathrm{NiL}]^{2+}$ & -1.86 & & & 2.83 & 3.629 \\
\hline${ }^{1}[\mathbf{N i L H}]^{0}$ & -160.655 & -451.90 & -343.55 & -150.26 & 1.887 \\
\hline${ }^{2}[\mathrm{NiLH}]^{+}$ & -7.906 & -106.86 & -66.32 & -3.24 & 2.079 \\
\hline
\end{tabular}




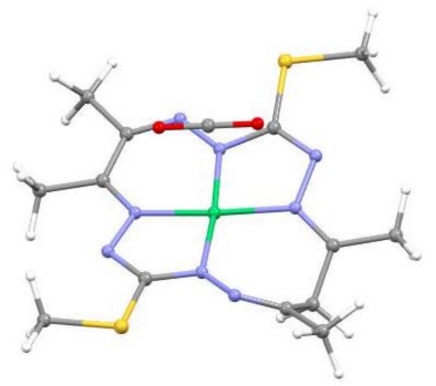

(a)

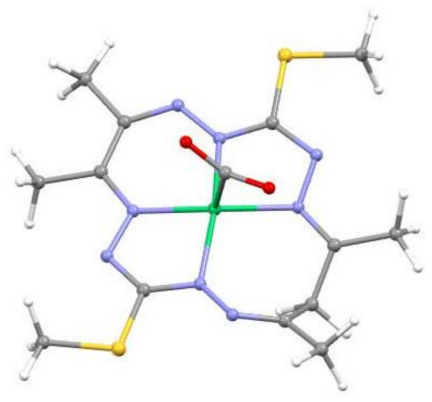

(c)

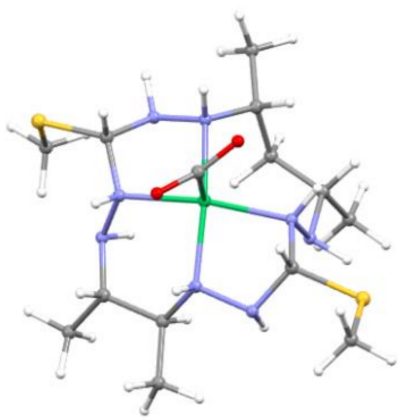

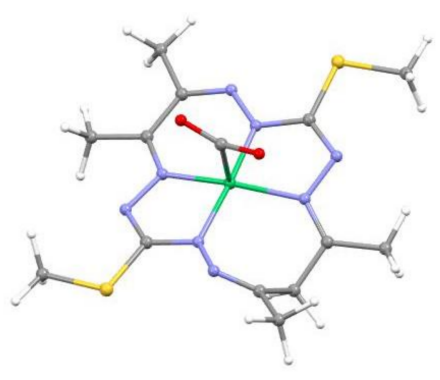

(b)

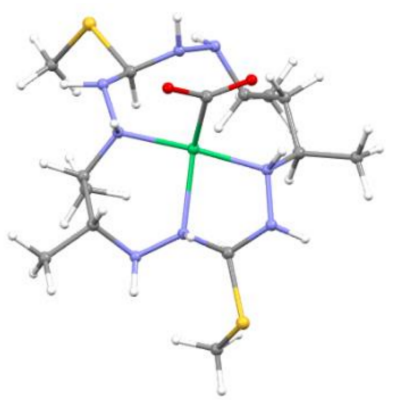

(d)

(e)

Figure 2. Structure of studied complexes with $\mathrm{CO}_{2}:\left(\right.$ a) ${ }^{1}\left[\mathrm{NiL}-\mathrm{CO}_{2}\right]^{0}$, (b) ${ }^{1}\left[\mathrm{NiL}_{\mathrm{fr}} \mathrm{CO}_{2}\right]^{0}$, (c) ${ }^{3}[\mathrm{NiL}$ $\left.\mathrm{CO}_{2}\right]^{2-},(\mathrm{d}){ }^{1}\left[\mathrm{NiLH}-\mathrm{CO}_{2}\right]^{0}$, and $(\mathbf{e})^{2}\left[\mathrm{NiLH}-\mathrm{CO}_{2}\right]^{+}$. Colour scheme: green $\mathrm{Ni}$, yellow $\mathrm{S}$, blue $\mathrm{N}$, grey $\mathrm{C}$, and white $\mathrm{H}$.

Changes in the geometry upon $\mathrm{CO}_{2}$ binding are the most pronounced for the ${ }^{1}[\mathbf{N i L H}]^{0}$ complex. The shortening of the and Ni-N(5) (-0.5 $\AA$ ) distance shows the largest difference, while the Ni-N(1) becomes $3.08 \AA$ long, see Table S2. The $\mathrm{CO}_{2}$ molecule itself is bent in the complex, leading to the $\mathrm{O}-\mathrm{C}-\mathrm{O}$ angle of $129^{\circ}$ in ${ }^{1}\left[\mathbf{N i L H}-\mathbf{C O}_{2}\right]^{0}, 147^{\circ}$ in ${ }^{2}\left[\mathbf{N i L H}-\mathrm{CO}_{2}\right]^{+}$, and $138^{\circ}$ in ${ }^{3}\left[\mathrm{NiL}-\mathrm{CO}_{2}\right]^{2-}$, in contrast to the linear geometry $\left(180^{\circ}\right)$ of the gas phase $\mathrm{CO}_{2}$ molecule, or $\mathrm{CO}_{2}$ that did not directly bind to the Ni centre in the ${ }^{1}\left[\mathrm{NiL}-\mathrm{CO}_{2}\right]^{0}$ complex (see Figure 2a and Figure S1). In ${ }^{1}\left[\mathrm{NiL}_{\mathrm{fr}} \mathrm{CO}_{2}\right]^{0}$ (see Figure $2 \mathrm{~b}$ ), the structure optimization also resulted in a bent $\mathrm{CO}_{2}$ geometry $\left(145^{\circ}\right)$.

\subsection{MPA and QTAIM Charges}

MPA Ni charges (see Table 2 and Table S3a,b) agree well with those obtained from QTAIM (see Table 2 and Table S4a,b). The MPA charges of the remaining atoms in the studied systems are compiled in Table S3a,b, and the QTAIM charges are shown in Table S4a,b. The difference between MPA and QTAIM charges are particularly large for the carbon and oxygen atoms of $\mathrm{CO}_{2}$. 
Table 2. B3LYP/6-311G* MPA and QTAIM charges of chosen atoms of the studied complexes.

\begin{tabular}{ccccccc}
\hline & \multicolumn{2}{c}{ Ni } & \multicolumn{2}{c}{ C } & \multicolumn{2}{c}{ O * } \\
\hline & MPA & QTAIM & MPA & QTAIM & MPA & QTAIM \\
\hline${ }^{3}[\mathrm{NiL}]^{2-}$ & 0.73 & 0.74 & - & - & - & - \\
${ }^{1}[\mathrm{NiL}]^{2-}$ & 0.89 & 0.89 & - & - & - & - \\
${ }^{2}[\mathrm{NiL}]^{-}$ & 0.96 & 0.94 & - & - & - & - \\
${ }^{1}[\mathrm{NiL}]^{0}$ & 1.00 & 0.96 & - & - & - & - \\
${ }^{2}[\mathrm{NiL}]^{+}$ & 1.05 & 0.99 & - & - & - & - \\
${ }^{1}[\mathrm{NiL}]^{2+}$ & 1.10 & 1.03 & - & - & - & - \\
\hline${ }^{3}[\mathrm{NiL-CO}]^{2-}$ & 1.06 & 0.94 & 0.11 & 1.66 & -0.41 & -1.16 \\
${ }^{1}\left[\mathrm{NiL} \mathrm{frO}_{2}\right]^{0}$ & 1.10 & 1.00 & 0.21 & 1.81 & -0.32 & -1.10 \\
${ }^{1}\left[\mathrm{NiL}-\mathrm{CO}_{2}\right]^{0}$ & 1.00 & 0.96 & 0.48 & 2.15 & -0.25 & -1.08 \\
\hline${ }^{1}[\mathrm{NiLH}]^{0}$ & 0.04 & 0.15 & - & - & - & - \\
${ }^{2}[\mathrm{NiLH}]^{+}$ & 0.76 & 0.66 & - & - & - & - \\
${ }^{1}[\mathrm{NiLH}]^{2+}$ & 1.05 & 0.94 & - & - & - & - \\
\hline${ }^{1}\left[\mathrm{NiLH}-\mathrm{NO}_{2}\right]^{0}$ & 0.84 & 0.68 & 0.03 & 1.44 & -0.48 & -1.21 \\
${ }^{2}\left[\mathrm{NiLH}-\mathrm{NO}_{2}\right]^{+}$ & 1.15 & 0.89 & 0.19 & -0.10 & -0.33 & -0.08 \\
\hline $\mathrm{CO}_{2}$ & - & - & 0.53 & 2.15 & -0.26 & -1.08 \\
\hline${ }^{*}$ average value of the O atoms charge from the $\mathrm{CO}_{2}$ molecule & & &
\end{tabular}

According to MPA, the Ni charges of [NiL] are close to one (Table 2) in all of the investigated oxidation states of these complexes. This points to a ligand-centred reduction for both the one and two-electron reduced species, without a significant change on the central atom. For the two-electron reduced ${ }^{1}[\mathrm{NiL}]^{2-}$ species, the Ni MPA charge changes only by 0.11 e compared to ${ }^{1}[\mathrm{NiL}]^{0}$ and by $0.27 \mathrm{e}$ for ${ }^{3}[\mathrm{NiL}]^{2-}$. Still, the AO populations in the case of ${ }^{1}[\mathrm{NiL}]^{2-}$ change only due to a stronger $\mathrm{Ni}$ ligand interaction (raise of the $\mathrm{s}_{\sigma}$ and $d_{x^{2}-y^{2}}$ populations), while the presence of $d_{x^{2}-y^{2}}$ spin density suggests a reduction of $\mathrm{Ni}$ to the oxidation state $\mathrm{I}$ in ${ }^{3}[\mathrm{NiL}]^{2-}$, see Table 3 and the coming section. In the [NiLH] complex, we observed a decrease in the $\mathrm{Ni}$ charge upon subsequent reductions from one to almost zero $\left(1.05\right.$ e for ${ }^{1}[\mathrm{NiLH}]^{2+}, 0.76$ e for ${ }^{2}[\mathrm{NiLH}]^{+}$and 0.04 e for $\left.{ }^{1}[\mathrm{NiLH}]^{0}\right)$, which points to the reduction on the central atom, unlike in the ${ }^{2}[\mathrm{NiL}]^{-}$and ${ }^{1}[\mathrm{NiL}]^{2-}$ complexes. These physical MPA charges can be attributed to oxidation states II, I, and 0 in the case of ${ }^{1}[\mathrm{NiL}]^{0} /{ }^{1}[\mathrm{NiLH}]^{2+},{ }^{3}[\mathrm{NiL}]^{2-} /{ }^{2}[\mathrm{NiLH}]^{+}$and ${ }^{1}[\mathrm{NiLH}]^{0}$, respectively. More details on the considered oxidation states will be given below (see the MPA d-orbitals Ni populations, Localized orbitals and DAFH analysis sections).

The presented charges point to an increase of the Ni charge when the $\mathrm{CO}_{2}$ molecule binds to ${ }^{1}[\mathbf{N i L H}]^{0},{ }^{2}[\mathbf{N i L H}]^{+}$, and ${ }^{3}[\mathrm{NiL}]^{2-}$ (see Table 2 and Table S3a,b), i.e., a charge transfer from $\mathrm{Ni}$ to $\mathrm{CO}_{2}$ is observed, where $\mathrm{Ni}$ is oxidized and $\mathrm{CO}_{2}$ is reduced. The most significant change in Ni charge in the presence of $\mathrm{CO}_{2}$ is found for ${ }^{1}\left[\mathrm{NiLH}-\mathrm{CO}_{2}\right]^{0}$, with a loss of ca. 0.8 (0.53) e when compared to ${ }^{1}[\mathrm{NiLH}]^{0} \mathrm{MPA}$ (QTAIM) charges. Furthermore, the bound $\mathrm{CO}_{2}$ molecule in ${ }^{1}\left[\mathrm{NiLH}-\mathrm{CO}_{2}\right]^{0}$ has an MPA (QTAIM) charge of $-0.93(-0.98)$ e. Hence, the central $\mathrm{Ni}$ atom becomes oxidized (from 0 to $\mathrm{I}$ ) and the $\mathrm{CO}_{2}$ molecule reduced (formally from 0 to -1 ) when comparing ${ }^{1}\left[\mathrm{NiLH}-\mathrm{CO}_{2}\right]^{0}$ with ${ }^{1}[\mathrm{NiLH}]^{0}$ and the free $\mathrm{CO}_{2}$ molecule (see Table 2). In ${ }^{2}\left[\mathrm{NiLH}-\mathrm{CO}_{2}\right]^{+}$and ${ }^{3}\left[\mathrm{NiL}-\mathrm{CO}_{2}\right]^{2-}$, the Ni MPA (QTAIM) charge has increased by ca. +0.39 and $+0.38(+0.23$ and +0.20$)$ e with respect to ${ }^{2}[\mathrm{NiLH}]^{+}$and ${ }^{3}[\mathrm{NiL}]^{2-}$. The bound $\mathrm{CO}_{2}$ molecule carries an MPA (QTAIM) charge of $-0.47(-0.46)$ e in ${ }^{2}\left[\mathrm{NiLH}-\mathrm{CO}_{2}\right]^{+}$and $-0.71(-0.66)$ e in ${ }^{3}\left[\mathrm{NiL}-\mathrm{CO}_{2}\right]^{2-}$. On the contrary, an Ni charge of ${ }^{1}\left[\mathrm{NiL}_{\mathrm{fr}} \mathrm{CO}_{2}\right]^{0}$ and ${ }^{1}\left[\mathrm{NiL}-\mathrm{CO}_{2}\right]^{0}$ changes only slightly or remains unchanged, when compared to ${ }^{1}[\mathrm{NiL}]^{0}$. Hence, the polarization of the $\mathrm{CO}_{2}$ molecule experiences only a slight change in ${ }^{1}\left[\mathrm{NiL}-\mathrm{CO}_{2}\right]^{0}$ when compared to the free $\mathrm{CO}_{2}$ (see Table 2). In ${ }^{1}\left[\mathrm{NiL}_{\mathrm{fr}} \mathrm{CO}_{2}\right]^{0}$, the $\mathrm{CO}_{2}$ molecule gains 0.43 (0.39) e based on MPA (QTAIM), although the actual change of Ni charge is only 0.1 e. Nevertheless, such charge transfer, from the macrocycle ligand to $\mathrm{CO}_{2}$, seems to be energetically disfavoured. 
Table 3. B3LYP /6-311G* formal oxidation state of Ni and Mulliken d-orbital populations on the central atoms of the studied complexes (spin population for chosen triplet state complexes in parenthesis).

\begin{tabular}{|c|c|c|c|c|c|c|c|c|}
\hline & $\begin{array}{l}\text { Formal ox. } \\
\text { State of Ni }\end{array}$ & $\mathrm{d}_{\mathrm{z}^{2}}$ & $d_{x z}$ & $d_{y z}$ & $\mathbf{d}_{\mathbf{x}^{2}-\mathbf{y}^{2}}$ & $d_{x y}$ & $\mathbf{s}_{\sigma}$ & $\mathrm{d}_{\text {total }}$ \\
\hline${ }^{3}[\mathrm{NiL}]^{2-}$ & I & $\begin{array}{c}1.745 \\
(0.043)\end{array}$ & $\begin{array}{c}1.878 \\
(0.009)\end{array}$ & $\begin{array}{c}1.830 \\
(0.032)\end{array}$ & $\begin{array}{c}1.146 \\
(0.768)\end{array}$ & $\begin{array}{c}1.886 \\
(0.006)\end{array}$ & $\begin{array}{c}0.693 \\
(-0.055)\end{array}$ & $\begin{array}{c}8.487 \\
(0.858)\end{array}$ \\
\hline${ }^{1}[\mathrm{NiL}]^{2-}$ & II & 1.797 & 1.925 & 1.903 & 0.846 & 1.910 & 0.684 & 8.381 \\
\hline${ }^{2}[\mathrm{NiL}]^{-}$ & II & 1.820 & 1.924 & 1.908 & 0.796 & 1.912 & 0.639 & 8.360 \\
\hline${ }^{1}[\mathrm{NiL}]^{0}$ & II & 1.835 & 1.920 & 1.906 & 0.791 & 1.911 & 0.599 & 8.363 \\
\hline${ }^{2}[\mathrm{NiL}]^{+}$ & II & 1.851 & 1.903 & 1.908 & 0.790 & 1.913 & 0.562 & 8.365 \\
\hline${ }^{1}[\mathrm{NiL}]^{2+}$ & II & 1.868 & 1.893 & 1.886 & 0.803 & 1.915 & 0.527 & 8.365 \\
\hline${ }^{3}\left[\mathrm{NiL}-\mathrm{CO}_{2}\right]^{2-}$ & II & $\begin{array}{c}1.420 \\
(0.273)\end{array}$ & $\begin{array}{c}1.918 \\
(0.009)\end{array}$ & $\begin{array}{c}1.915 \\
(0.012)\end{array}$ & $\begin{array}{c}1.205 \\
(0.774)\end{array}$ & $\begin{array}{c}1.911 \\
(0.009)\end{array}$ & $\begin{array}{c}0.553 \\
(-0.012)\end{array}$ & $\begin{array}{c}8.343 \\
(1.077)\end{array}$ \\
\hline${ }^{1}\left[\mathrm{NiL}_{\mathrm{fr}} \mathrm{CO}_{2}\right]^{0}$ & II & 1.562 & 1.922 & 1.938 & 0.951 & 1.923 & 0.490 & 8.296 \\
\hline${ }^{1}\left[\mathrm{NiL}-\mathrm{CO}_{2}\right]^{0}$ & II & 1.833 & 1.919 & 1.907 & 0.794 & 1.911 & 0.602 & 8.364 \\
\hline${ }^{1}[\mathrm{NiLH}]^{0}$ & 0 & 1.649 & 1.861 & 1.890 & 1.527 & 1.829 & 1.135 & 8.756 \\
\hline${ }^{2}[\mathrm{NiLH}]^{+}$ & I & 1.736 & 1.919 & 1.908 & 1.123 & 1.897 & 0.662 & 8.583 \\
\hline${ }^{1}[\mathrm{NiLH}]^{2+}$ & II & 1.836 & 1.941 & 1.933 & 0.762 & 1.928 & 0.588 & 8.400 \\
\hline${ }^{1}\left[\mathrm{NiLH}-\mathrm{CO}_{2}\right]^{0}$ & I & 1.329 & 1.892 & 1.870 & 1.636 & 1.890 & 0.577 & 8.617 \\
\hline${ }^{2}\left[\mathrm{NiLH}-\mathrm{CO}_{2}\right]^{+}$ & II & 1.504 & 1.928 & 1.929 & 1.165 & 1.923 & 0.426 & 8.448 \\
\hline
\end{tabular}

\subsection{MPA d-Orbital Ni Populations}

The B3LYP/6-311G* MPA d-orbital populations, as well as the excess of $s_{\sigma}$ (sum of s-population minus six electrons assumed to occupy $1 \mathrm{~s}, 2 \mathrm{~s}$ and $3 \mathrm{~s}$ shells) of the central $\mathrm{Ni}$ atom, are summarized in Table 3. Eight closed-shell $d$ electrons $\left(d_{x z}, d_{y z}, d_{x y}, d_{x^{2}-y^{2}}\right.$ and $\mathrm{d}_{\mathrm{z}^{2}}$ ) have been found on $\mathrm{Ni}$ for all [NiL] species, as well as in the case of the ${ }^{1}[\mathbf{N i L H}]^{2+}$ complex, and therefore one can assign a formal oxidation state of II to the nickel (albeit the physical, and/or total, $\mathrm{d}$ population is between 8.3-8.5). In the case of ${ }^{1}[\mathrm{NiLH}]^{0}$, the value of the total $\mathrm{d}$ population $\left(\mathrm{d}_{\text {total }}\right)$ is close to nine $(8.8 \mathrm{e})$ which together with the $1.1 \mathrm{e} \mathrm{s}_{\sigma}$ population indicate an oxidation state of 0 on nickel in ${ }^{1}[\mathrm{NiLH}]^{0}$. In particular, the occupation of $\mathrm{Ni}$ d-orbitals agrees with the crystal field theory prediction for a squareplanar geometry of both $\left[\mathrm{Ni}^{\mathrm{II}} \mathbf{L}\right]$ and $\left[\mathrm{Ni}^{\mathrm{II}} \mathbf{L H}\right]$-like species, with the doubly occupied $\mathrm{d}_{\mathrm{xz}}$, $\mathrm{d}_{\mathrm{yz}}$ and $\mathrm{d}_{\mathrm{xy}}$ orbitals, an almost doubly occupied $\mathrm{d}_{\mathrm{z}^{2}}$, and the $\mathrm{d}_{\mathrm{x}^{2}-\mathrm{y}^{2}}$ orbital, involved in the $\sigma$ coordination. When comparing ${ }^{1}[\mathrm{NiL}]^{0}$ with the oxidized $\left({ }^{2}[\mathbf{N i L}]^{+}\right.$and $\left.{ }^{1}[\mathrm{NiL}]^{2+}\right)$ and reduced $\left({ }^{2}[\mathrm{NiL}]^{-}\right)$species, there are no significant changes in the d-orbital populations. On the other hand, comparing ${ }^{1}[\mathrm{NiL}]^{0}$ with ${ }^{3}[\mathrm{NiL}]^{2-}$, one can identify an increase in the $\mathrm{d}_{\mathrm{x}^{2}-\mathrm{y}^{2}}$ $(0.35 \mathrm{e})$ and $\mathrm{s}_{\sigma}(0.1 \mathrm{e})$ populations for the doubly charged species ${ }^{3}[\mathrm{NiL}]^{2-}$ (including the presence of a nonnegligible spin population in $\mathrm{d}_{\mathrm{x}^{2}-\mathrm{y}^{2}}$, see Table 3). In the case of [NiLH], the most significant changes have been revealed for the ${ }^{1}[\mathrm{NiLH}]^{0}$ complex, where the $\mathrm{d}_{\mathrm{z}^{2}}$ population decreased by $0.09 \mathrm{e}$ and $\mathrm{d}_{\mathrm{x}^{2}-\mathrm{y}^{2}}$ and $\mathrm{s}_{\sigma}$ increased their populations by 0.35 and $0.48 \mathrm{e}$, respectively, when compared to ${ }^{1}[\mathrm{NiLH}]^{2+}$. In ${ }^{2}[\mathrm{NiLH}]^{+}$, a significant change of $-0.36 \mathrm{e}$ is observed for the $\mathrm{d}_{\mathrm{x}^{2}-\mathrm{y}^{2}}$ orbital population compared to ${ }^{1}[\mathrm{NiLH}]^{2+}$. Thus, the individual d-populations closely follow the conclusion derived from the MPA and QTAIM charge analysis that the reduction of [NiLH] occurs on the central atom unlike in [NiL] complexes. Still, the particular d-populations of ${ }^{1}[\mathrm{NiLH}]^{0}$ can be less straightforwardly assigned to a close-shell or formally open-shell character as suggested in the crystal field theory. This is caused by the large distortion of the coordination polyhedron from a square-planar structure in ${ }^{1}[\mathrm{NiLH}]^{0}$ as mentioned above.

For completeness, Ni atomic orbitals that change their populations when the studied

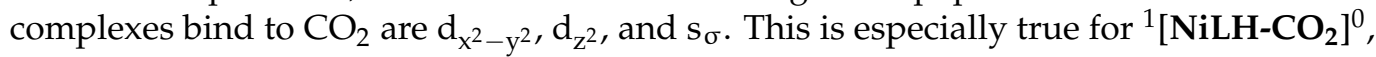
where $\mathrm{d}_{\mathrm{z}^{2}}$ and $\mathrm{s}_{\sigma}$ decrease their populations by 0.32 and $0.57 \mathrm{e}$, respectively, and $\mathrm{d}_{\mathrm{x}^{2}-\mathrm{y}^{2}}$ increases by $0.11 \mathrm{e}$. In the case of ${ }^{3}\left[\mathrm{NiL}-\mathrm{CO}_{2}\right]^{2-}$ and ${ }^{1}\left[\mathrm{NiL}_{\mathrm{fr}} \mathrm{CO}_{2}\right]^{0}, \mathrm{~d}_{\mathrm{z}^{2}}$ populations de- 
crease by ca. 0.3 e, $s_{\sigma}$ a decrease of 0.1 e while $d_{x^{2}-y^{2}}$ and $d_{x y}$ becomes only slightly more populated. A similar situation is also found in the ${ }^{2}\left[\mathrm{NiL}-\mathrm{CO}_{2}\right]^{+}$, where $\mathrm{d}_{\mathrm{z}^{2}}$ and $\mathrm{s}_{\sigma}$ populations decrease by ca. $0.24 \mathrm{e}$, while $\mathrm{d}_{\mathrm{x}^{2}-\mathrm{y}^{2}}$ remains unchanged.

\subsection{QTAIM BCP Analysis}

Additional information on the electronic structure, besides the robust atomic charges (spins) discussed above, can be obtained from the QTAIM analysis including the bond critical point $(\mathrm{BCP})$ characteristics (electron density $(\rho)$, its Laplacian $(\Delta \rho)$ and ellipticity $(\varepsilon))$ and the delocalization index (DI). DI can be used to estimate the formal bond order and/or bond strength. BCP characteristics and DIs are compiled in Table S5a,b. The change in the Ni-N BCP characteristics upon reduction are the most obvious for ${ }^{1}[\mathrm{NiLH}]^{0}$. The $\mathrm{Ni}-\mathrm{N}(1)$ and $\mathrm{Ni}-\mathrm{N}(5)$ bond lengths become elongated after reduction to 2.96 and $2.77 \AA$ (BCPs are still present), which leads to lower values of BCP $\rho, \Delta \rho$, and DIs and we observed a significant increase in the value of $\mathrm{Ni}-\mathrm{N}(1)$ and $\mathrm{Ni}-\mathrm{N}(5) \mathrm{BCP}$ ellipticities $\varepsilon=0.79$ and 0.38 , respectively. The Ni-N(5) bond becomes shorter once $\mathrm{CO}_{2}$ binds to the complex and this BCP ellipticity value in ${ }^{1}\left[\mathrm{NiLH}-\mathrm{CO}_{2}\right]^{0}$ decreases and becomes numerically reasonable, see in the coming text. The problem with the Ni-N(1) and Ni-N(5) ellipticities of ${ }^{1}[\mathrm{NiLH}]^{0}$ is the large interatomic distance which leads to small BCP Hessian eigenvalues $\left(\lambda_{\mathrm{i}}\right)$, which grossly affect the ellipticity (where ellipticity is defined as $\varepsilon=\lambda_{1} / \lambda_{2}-1$ ), BCP Hessian eigenvalues are presented in Table S5a,b. Although this issue does not completely diminish for $\mathrm{Ni}-\mathrm{N}(1)$ with a bond length of $2.97 \AA$ and $\varepsilon=0.33$. The $\mathrm{Ni}-\mathrm{N}(3)$ and $\mathrm{Ni}-\mathrm{N}(7)$ bonds become slightly longer when comparing ${ }^{1}\left[\mathrm{NiLH}-\mathrm{CO}_{2}\right]^{0}$ and ${ }^{1}[\mathrm{NiLH}]^{0}$, which similarly affects the particular BCP characteristics, as found for ${ }^{3}[\mathrm{NiL}]^{2-}$. In the ${ }^{1}\left[\mathrm{NiLH}-\mathrm{CO}_{2}\right]^{0}$ complex, the BCP value of $\rho$ (0.93), $\Delta \rho$ (3.50), as well as the value of DI (0.86) of the $\mathrm{Ni}-\mathrm{C}_{\mathrm{CO} 2}$ bond are the largest, indicating the strongest dative interaction between the [NiLH] complex and $\mathrm{CO}_{2}$, which naturally correlates with the shortest $\mathrm{Ni}-\mathrm{C}_{\mathrm{CO} 2}$ bond length. In the ${ }^{3}\left[\mathrm{NiL}-\mathrm{CO}_{2}\right]^{2-}$ and ${ }^{2}\left[\mathrm{NiLH}-\mathrm{CO}_{2}\right]^{+}$complexes, the changes in the Ni-N BCP characteristics after binding of the $\mathrm{CO}_{2}$ molecule are not dramatic, and we observe only a small elongation of the $\mathrm{Ni}-\mathrm{N}$ bonds, which in turn leads to lower values of BCP $\rho, \Delta \rho$, and DIs. When compared to the free $\mathrm{CO}_{2}$, we have also observed a small increase of the $\mathrm{C}-\mathrm{O}$ bond ellipticity which correlates with the bent structure of the bound $\mathrm{CO}_{2}$. Still, the $\mathrm{C}-\mathrm{O}$ DIs even in ${ }^{1}\left[\mathrm{NiLH}-\mathrm{CO}_{2}\right]^{0}$ decrease only by 0.12 with respect to the free $\mathrm{CO}_{2}$. In the case of ${ }^{1}\left[\mathrm{NiL}_{\mathrm{fr}} \mathrm{CO}_{2}\right]^{0}$ with the $\mathrm{Ni}-\mathrm{C}_{\mathrm{CO} 2}$ distance frozen, as well as in the case of ${ }^{2}\left[\mathrm{NiLH}-\mathrm{CO}_{2}\right]^{+}$, we have not observed any differences in the $\mathrm{C}-\mathrm{O} \mathrm{BCP}$ characteristics compared to the free $\mathrm{CO}_{2}$, despite a non-zero $\mathrm{Ni}-\mathrm{C}_{\mathrm{CO} 2} \mathrm{DI}$. In the case of ${ }^{1}\left[\mathrm{NiL}-\mathrm{CO}_{2}\right]^{0}$, the $\mathrm{Ni}-\mathrm{C}_{\mathrm{CO} 2} \mathrm{BCP}$ has very low $\rho, \Delta \rho$, and DI values (0.003, 0.010 and 0.008 , respectively) and the outcome of the QTAIM analysis when comparing the NiL unit in ${ }^{1}\left[\mathrm{NiL}-\mathrm{CO}_{2}\right]^{0}$ and ${ }^{1}[\mathrm{NiL}]^{0}$ is the same (not shown).

\subsection{Localized Orbitals, Frontier Orbitals and DAFH Analysis}

To further elucidate the relation between the electronic structure and the $\mathrm{CO}_{2}$ affinity of the studied complexes, localized orbitals (LOC) and domain averaged Fermi holes (DAFH) analysis has been performed. In the present cases, the $\mathrm{Ni}$ and $\mathrm{CO}_{2}$ atoms have been chosen as DAFH domains for the inspection of the $\mathrm{Ni}-\mathrm{C}_{\mathrm{CO} 2}$ bonding situation. As mentioned in the Methods-Computation Details section, the LOC and DAFH eigenvectors were analysed using the $\mathrm{Ni}-\mathrm{C}_{\mathrm{CO} 2}$ bond aligned geometries (the $\mathrm{Ni}-\mathrm{C}_{\mathrm{CO} 2}$ bond was aligned in the $z$-axis direction). LOC populations are shown in Table 4 and DAFH eigenvectors and eigenvalues are compiled in Figure 3. The essential Ni- $\mathrm{C}_{\mathrm{CO} 2}$ bond contributions are coming from the $\mathrm{d}_{\mathrm{z}^{2}}$ atomic orbital of the Ni atom and in the C atoms case, from $2 \mathrm{~s}$ and $2 \mathrm{p}_{\mathrm{z}}$ atomic orbitals (AOs), according to LOC populations in Table 4 and the DAFH eigenvector shapes in Figure 3. The localized d-orbitals on the central atom are compiled in Table S6a,b, indicating a $\mathrm{d}^{8}$ electronic configuration in the $[\mathrm{NiL}]$ complexes except for ${ }^{3}[\mathrm{NiL}]^{2-}$. In the ${ }^{3}[\mathrm{NiL}]^{2-}$ case, the localization procedure yields a formal d population of 9 on the $\mathrm{Ni}$ atom, which is distributed over $5 \alpha$ and $4 \beta$ LOCs. In the ${ }^{1}[\mathbf{N i L H}]^{0},{ }^{2}[\mathbf{N i L H}]^{+}$and ${ }^{1}[\mathbf{N i L H}]^{2+}$ 
complexes, the localization procedure leads to formally $\mathrm{d}^{10}, \mathrm{~d}^{9}$, and $\mathrm{d}^{8} \mathrm{Ni}$ LOCs, which correspond to the formal oxidation states 0 , I, and II, respectively. The DAFH analysis of ${ }^{1}[\mathbf{N i L H}]^{0}$ and ${ }^{1}[\mathbf{N i L}]^{0}$ agrees with the $\mathrm{d}^{10}$ and $\mathrm{d}^{8}$ configuration, 5 and 4 eigenvectors with occupation numbers $[1.93,1.92,1.88,1.83,1.62]$ and $[1.92,1.92,1.87,1.85]$ are present in the $\mathrm{Ni}$ basin, respectively. In the ${ }^{1}\left[\mathrm{NiLH}-\mathrm{CO}_{2}\right]^{0}$, the DAFH eigenvectors indicate a small polarization of the $\mathrm{Ni}-\mathrm{C}_{\mathrm{CO} 2}$ bond towards the $\mathrm{CO}_{2}$ molecule, i.e., the $\mathrm{Ni}$ basin contains 1.04 electrons, as well as the $\mathrm{CO}_{2}$ basin, in the $\mathrm{Ni}-\mathrm{C}_{\mathrm{CO} 2}$ eigenvector/bond (see Figure 3). Both DAFH eigenvectors show an interaction between the $2 \mathrm{~s}$ and $2 \mathrm{p}_{\mathrm{z}}$ orbitals of the carbon atom and the $\mathrm{d}_{\mathrm{z}^{2}}$ orbital of nickel. The DAFH analysis is in reasonable agreement with the results of the LOC procedure. Nevertheless, the LOC procedure shows a larger polarization of the $\mathrm{Ni}-\mathrm{C}_{\mathrm{CO} 2}$ bond with 1.48 electrons on the $\mathrm{C}$ atom and 0.80 electrons on the $\mathrm{Ni}$ atom (see Table 4), which would indicate a more dominant contribution from $\mathrm{C}$ to the unevenly shared electron pair and the $\sigma\left(\mathrm{Ni}-\mathrm{C}_{\mathrm{CO} 2}\right)$ bond having a $\mathrm{Ni}(\delta+)-\mathrm{CO}_{2}(\delta-)$ nature. (This overestimated polarization seems to be an artefact of the AO based analysis in the LOC procedure when compared to the QTAIM based atoms definition in DAFH). In the ${ }^{2}\left[\mathrm{NiLH}-\mathrm{CO}_{2}\right]^{+}$and ${ }^{3}\left[\mathrm{NiL}-\mathrm{CO}_{2}\right]^{2-}$, the polarization of the $\mathrm{Ni}-\mathrm{C}_{\mathrm{CO} 2}$ bond is opposite to ${ }^{1}\left[\mathrm{NiLH}-\mathrm{CO}_{2}\right]^{0}$ and these $\mathrm{Ni}-\mathrm{C}_{\mathrm{CO} 2} \mathrm{DAFH}$ eigenvectors show the dominant contribution from the $\mathrm{Ni}$ atom. More specifically, the $\mathrm{Ni}$ basin contains the following part of the $\mathrm{Ni}-\mathrm{C}_{\mathrm{CO} 2}$ eigenvectors: $\alpha(0.88) / \beta(0.63)$ for ${ }^{2}\left[\mathrm{NiLH}-\mathrm{CO}_{2}\right]^{+}$and $\alpha(0.84) / \beta(0.57)$ for ${ }^{3}\left[\mathrm{NiL}-\mathrm{CO}_{2}\right]^{2-}(\mathrm{a}$ total two electrons). As a complement, the $\mathrm{CO}_{2}$ basin has the following composition of eigenvector shared with Ni: $\alpha(0.13) / \beta(0.38)$ and $\alpha(0.21) / \beta(0.47)$, respectively, see Figure 3 . The LOC procedure is in qualitative agreement with the particular DAFHs of ${ }^{2}[\mathrm{NiLH}-$ $\left.\mathrm{CO}_{2}\right]^{+}$(see Table 4 and Figure 3). In ${ }^{1}\left[\mathrm{NiL}_{\mathrm{fr}} \mathrm{CO}_{2}\right]^{0}$, the contribution of the $\mathrm{C}$ atom to the unevenly shared electron pair of this bond is only 0.44 electrons for both methods (see Table 4 and Figure 3). However, it should be noted that this is an enforced interaction between $\mathrm{Ni}$ and $\mathrm{C}$.

To illustrate further differences between ${ }^{1}[\mathbf{N i L}]^{0}$ and ${ }^{1}[\mathbf{N i L H}]^{0}$, we will briefly discuss the frontier orbitals, see Figure S2a,b (pictorial representation without $\mathrm{CO}_{2}$ ) as well as S3a and S3b (pictorial representation with $\mathrm{CO}_{2}$ ). From Figure $\mathrm{S} 2 \mathrm{a}, \mathrm{b}$, it can be seen that the highest occupied molecular orbital (HOMO) as well as the lowest unoccupied molecular orbital (LUMO) of ${ }^{1}[\mathrm{NiL}]^{0}$ are both localized mainly on the macrocycle ligand, and are involved in $\pi$ interactions with only a small antibonding contribution of $\mathrm{d}(\mathrm{Ni})$ orbitals. The HOMO- 1 of ${ }^{1}[\mathrm{NiL}]^{0}$ has a $24.7 \% \mathrm{~d}_{\mathrm{yz}}$ contribution, see Figure S2a. Additional $\mathrm{d}$ contributions of Ni in MOs of ${ }^{1}[\mathrm{NiL}]^{0}$ can be found in the lower orbitals HOMO-4 $(70.7 \%$ $\left.\mathrm{d}_{\mathrm{z}^{2}}\right)$, HOMO-6 $\left(34.9 \% \mathrm{~d}_{\mathrm{xz}}\right)$, HOMO-7 $\left(29.0 \% \mathrm{~d}_{\mathrm{xz}}\right)$, or HOMO-10 (53.7\% $\left.\mathrm{d}_{\mathrm{yz}}\right)$ (not shown). The situation with the Ni d-character in the frontier orbitals of ${ }^{1}[\mathrm{NiL}]^{2-}$ is not much different from ${ }^{1}[\mathrm{NiL}]^{0}$. The HOMO and HOMO-1 orbitals have $\pi$ ligand character and the $\mathrm{Ni}$ d-population becomes significant in the lower orbitals, i.e., HOMO-2 $\left(31.7 \% \mathrm{~d}_{\mathrm{xz}}\right)$, HOMO-3 $\left(30.4 \% \mathrm{~d}_{\mathrm{z}^{2}}, 17.9 \% \mathrm{~d}_{\mathrm{yz}}\right)$, HOMO-4 $\left(46.5 \% \mathrm{~d}_{\mathrm{z}^{2}}, 14.1 \% \mathrm{~d}_{\mathrm{yz}}\right)$, HOMO-5 $\left(42.7 \% \mathrm{~d}_{\mathrm{yz}}\right)$, or HOMO-9 $\left(35.9 \% \mathrm{~d}_{\mathrm{xz}}\right.$ and $\left.11.2 \% \mathrm{~d}_{\mathrm{xy}}\right)$ (not shown). On the other hand, in the ${ }^{1}[\mathbf{N i L H}]^{0}$ complex, HOMO to HOMO-4 are all localized predominantly on $\mathrm{Ni}$ (see HOMO and HOMO-1 in Figure S2b). In ${ }^{3}[\mathrm{NiL}]^{2-}$, HOMO-1, HOMO, and LUMO have a d(Ni) character, although being still involved in antibonding or non-boning $d(N i)-p(N)$ interactions with the macrocycle ligand (see Figure S2a,b). The Ni-C $\mathrm{CO} 2$ interactions in ${ }^{1}\left[\mathrm{NiLH}-\mathrm{CO}_{2}\right]^{0}$, ${ }^{2}\left[\mathrm{NiLH}-\mathrm{CO}_{2}\right]^{+}$, and ${ }^{3}\left[\mathrm{NiL}-\mathrm{CO}_{2}\right]^{2-}$ can be seen in the plots of HOMO, $\beta-\mathrm{HOMO}$, and $\beta$-LUMO, respectively, see Figure S3. It is still fair to stress that for example in ${ }^{1}[\mathrm{NiLH}-$ $\left.\mathrm{CO}_{2}\right]^{0}$, it is not only the HOMO that is involved in the $\mathrm{Ni}-\mathrm{CO}_{2}$ interactions, but also, e.g., HOMO-1 to HOMO-4. Hence, the bonding picture taken with respect to a single MO can have some qualitative significance, but additional bonding features are often spread among a larger number of MOs due to the orthonormality conditions of the Hartree-Fock (Kohn-Sham) equations. 
Table 4. B3LYP /6-311G* LOC AO populations and atomic total contributions.

\begin{tabular}{|c|c|c|c|c|c|c|}
\hline & \multicolumn{4}{|c|}{ AO Populations } & \multicolumn{2}{|c|}{ Total } \\
\hline & $\mathrm{s}(\mathrm{Ni})$ & $\mathrm{d}_{\mathrm{z}^{2}}(\mathrm{Ni})$ & $\mathrm{s}(\mathrm{C})$ & $\mathrm{p}_{\mathrm{z}}(\mathrm{C})$ & $\mathbf{N i}$ & $\mathrm{C}$ \\
\hline${ }^{1}\left[\mathrm{NiL}_{\mathrm{fr}} \mathrm{CO}_{2}\right]^{0}$ & 0.18 & 1.38 & 0.17 & 0.27 & 1.56 & 0.44 \\
\hline${ }^{3}\left[\mathrm{NiL}-\mathrm{CO}_{2}\right]^{2-} \alpha$ & 0.08 & 0.74 & 0.04 & 0.07 & 0.82 & 0.11 \\
\hline${ }^{3}\left[\mathrm{NiL}-\mathrm{CO}_{2}\right]^{2-} \beta$ & 0.12 & 0.36 & 0.32 & 0.30 & 0.48 & 0.62 \\
\hline${ }^{2}\left[\mathrm{NiLH}-\mathrm{CO}_{2}\right]^{+} \alpha$ & 0.09 & 0.81 & 0.02 & 0.05 & 0.93 & 0.07 \\
\hline${ }^{2}\left[\mathrm{Ni} \mathrm{LH}-\mathrm{CO}_{2}\right]^{+} \beta$ & 0.14 & 0.53 & 0.17 & 0.23 & 0.66 & 0.40 \\
\hline${ }^{1}\left[\mathrm{Ni} \mathrm{LH}-\mathrm{CO}_{2}\right]^{0}$ & 0.18 & 0.62 & 0.62 & 0.52 & 0.80 & 1.16 \\
\hline
\end{tabular}

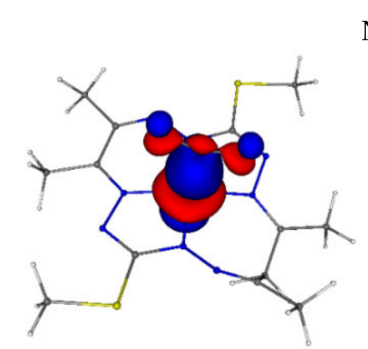

(a)

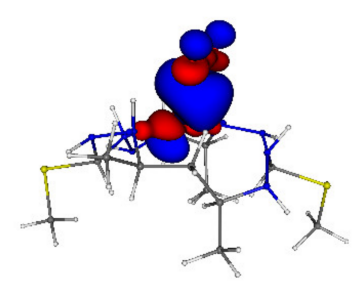

(c)

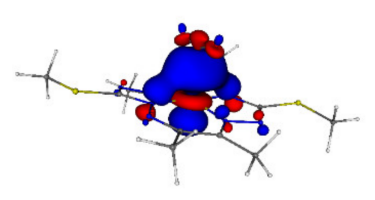

(e)

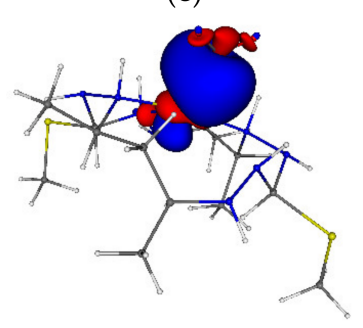

(g)

Ni Basin

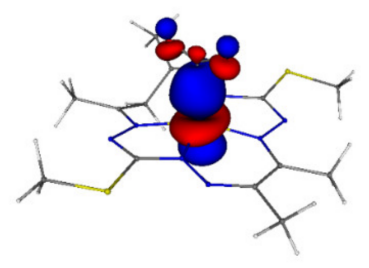

(b)

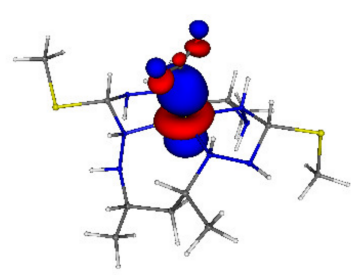

(d)

$\mathrm{CO}_{2}$ basin

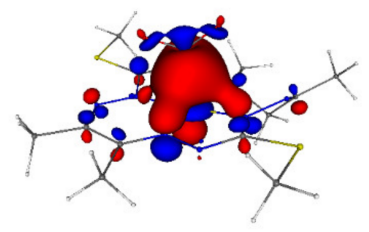

(f)

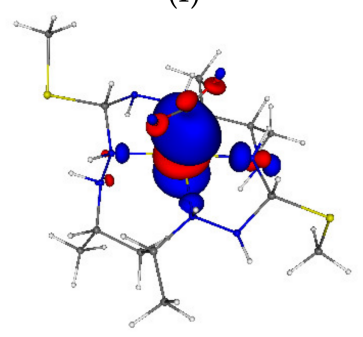

(h)

Figure 3. (a) ${ }^{1}\left[\mathrm{NiL}_{\mathrm{fr}} \mathrm{CO}_{2}\right]^{0}$ (1.62); (b) ${ }^{3}\left[\mathrm{NiL}-\mathrm{CO}_{2}\right]^{2-} \alpha(0.84) / \beta(0.57) ;$ (c) ${ }^{1}\left[\mathrm{NiLH}-\mathrm{CO}_{2}\right]^{0}$ (1.04); (d) ${ }^{2}\left[\mathrm{NiLH}-\mathrm{CO}_{2}\right]^{+} \alpha(0.88) / \beta(0.63) ; \quad$ (e) ${ }^{1}\left[\mathrm{NiL}_{\mathrm{fr}} \mathrm{CO}_{2}\right]^{0} \quad(0.44) ; \quad$ (f) ${ }^{3}\left[\mathrm{NiL}-\mathrm{CO}_{2}\right]^{2-} \alpha(0.21) / \beta(0.47)$; (g) ${ }^{1}\left[\mathrm{NiLH}-\mathrm{CO}_{2}\right]^{0}(1.04)$; (h) $\left[\mathrm{NiLH}-\mathrm{CO}_{2}\right]^{+} \alpha(0.13) / \beta(0.38)$. DAFH Ni-C $\mathrm{CO} 2$ eigenvectors at B3LYP $/ 6-$ $311 \mathrm{G}^{*}$ level of theory (isovalue 0.04 , red is negative and blue is positive). The $\mathrm{Ni}$ atom and $\mathrm{CO}_{2}$ have been chosen as the domain to analyse the bonding situation via DAFH analysis. DAFH eigenvalues for the particular basin/domain are given in parentheses. 
For instance, the $\mathrm{HOMO}$ of ${ }^{1}\left[\mathrm{NiLH}-\mathrm{CO}_{2}\right]^{0}$ has a $67.4 \% \mathrm{Ni}$ and $22.3 \% \mathrm{CO}_{2}$ composition $(\mathrm{MPA} \%)$, which formally gives a bond description like that present in ${ }^{1}\left[\mathrm{NiL}_{\mathrm{fr}} \mathrm{CO}_{2}\right]^{0} \mathrm{LOCs}$ in Table 4, i.e., the bond polarization is not appropriate, suggesting a $\mathrm{Ni}$ to $\mathrm{CO}_{2}$ dative (donor) interaction. If we consider ${ }^{3}\left[\mathrm{NiL}-\mathrm{CO}_{2}\right]^{2-}$, the HOMO and HOMO-1 do not show a bonding contribution at all, although $\mathrm{CO}_{2}$ is bound. Still, the frontier orbitals are useful when identifying the locus of a redox process (addition or removal of an electron), or when arguing about how the ligand $\pi$-system in [NiL] hampers the metal reduction, which is not the case in $[\mathrm{NiLH}]$.

\section{Methods-Computational Details}

Geometry optimizations of [NiL] and [NiLH] complexes with different charges and/or in various spin states were performed using the Gaussian16 [57] program suite employing the B3LYP/6311-G* computational protocol [58-64]. The unrestricted DFT formalism was used for open-shell systems (UB3LYP). The effect of dichloromethane as a solvent was approximated via the integral equation formalism polarizable continuum model (IEFPCM) $[65,66]$ as implemented in Gausian16. The stability of the optimized structures was confirmed by vibrational analysis. The counterpoise correction (CPC) method was applied to the interaction energy calculations to mitigate the basis set superposition error (BSSE), without including solvent effect $[67,68]$.

The $\mathrm{Ni}-\mathrm{C}_{\mathrm{CO} 2}$ bond character was analysed using the domain-averaged fermi holes (DAFHs) [69-71] in the DGrid 5.1 program package [72] employing the B3LYP/6-311G* fchk files from the Gaussian16 program package. The localized orbitals (LOC) and their Mulliken atomic population analysis (MPA) were obtained via the ORCA 4.2.0. package [73]. The cartesian z-axis has been aligned with the particular $\mathrm{Ni}-\mathrm{C}_{\mathrm{CO} 2}$ bond (denoted along bond aligned geometries), to allow for a further analysis of the $\mathrm{AO}$ contributions. The exploration of the topology of electron density utilized the quantum theory of atoms in molecules (QTAIM) [74] analysis using the AIMAll [75] package and the fchk Gaussian16 files. The Molekel package [76] was used for the visualization of the molecular orbitals and DAFH eigenvectors.

\section{Summary and Outlook}

The electronic structure of the ${ }^{1}[\mathrm{NiL}]^{0}$ complex is compared with the hydrogenated ${ }^{1}[\mathrm{NiLH}]^{2+}$ analogue. The analysis of the single and two-electron reduction has been performed and affinity of $\mathrm{CO}_{2}$ binding has been explored. Our results indicate that the $\mathrm{CO}_{2}$ reduction could possibly be achieved by involving the investigated complexes as mediators in electrocatalysis or electro-photocatalysis. We have identified a change of the oxidation state of the central $\mathrm{Ni}$ atom upon the reduction of ${ }^{1}\left[\mathrm{Ni}^{\mathrm{II}} \mathbf{L H}\right]^{2+}$, which leads to the affinity of $\mathrm{Ni}^{\mathrm{I}} / \mathrm{Ni}^{0}$ in the reduced species to $\mathrm{CO}_{2}$. Subsequently, $\mathrm{CO}_{2}$ is (partially) reduced and the creation of the $\mathrm{Ni}^{\mathrm{II}}-\mathrm{CO}_{2}{ }^{-}-/ \mathrm{Ni}^{\mathrm{I}}-\mathrm{CO}_{2}{ }^{-}$couple adduct as described in the literature [1,2] is confirmed. We have identified only a single $\mathrm{Ni}-\mathrm{C}_{\mathrm{CO} 2} \sigma$-bond even in the doubly reduced ${ }^{1}\left[\mathrm{NiLH}-\mathrm{CO}_{2}\right]^{0}$ species. In the case of [NiL], the one or two-electron reduction does not change the oxidation state of $\mathrm{Ni}^{\mathrm{II}}$. Hence, no affinity of the central atom in $[\mathrm{NiL}]$ towards $\mathrm{CO}_{2}$ is found in the ground state, while the triplet (excited) state of the double reduced ${ }^{3}[\mathrm{NiL}]^{2-}$ species is capable of binding $\mathrm{CO}_{2}$.

The DAFH eigenvectors, as well as LOC orbitals, indicate a $\mathrm{Ni}-\mathrm{C}_{\mathrm{CO} 2}$ polarization from the reduced $\mathrm{CO}_{2}{ }^{-}$species towards $\mathrm{Ni}^{\mathrm{I}}$ in ${ }^{1}\left[\mathrm{NiLH}-\mathrm{CO}_{2}\right]^{0}$, with the $\mathrm{Ni}-\mathrm{C}_{\mathrm{CO} 2}$ bond being the strongest among the studied $\mathrm{CO}_{2}$ complexes (according to DI, energetics and/or the bond length). In ${ }^{1}\left[\mathrm{NiL}_{\mathrm{fr}} \mathrm{CO}_{2}\right]^{0}$, one finds an enforced $\mathrm{Ni}\left(\mathrm{d}_{\mathrm{z}^{2}}\right)$ to $\mathrm{C}$ coordination (dative interaction). The $\mathrm{Ni}-\mathrm{C}_{\mathrm{CO} 2}$ interaction in ${ }^{2}\left[\mathrm{NiLH}-\mathrm{CO}_{2}\right]^{+}$and ${ }^{3}\left[\mathrm{NiL}-\mathrm{CO}_{2}\right]^{2-}$ can be considered an intermediate between ${ }^{1}\left[\mathrm{NiLH}-\mathrm{CO}_{2}\right]^{0}$ in the $\beta$ DAFHs or LOCs and ${ }^{1}\left[\mathrm{NiL}_{\mathrm{fr}} \mathrm{CO}_{2}\right]^{0}$ in the $\alpha$ ones.

Hence, the activation of $\left[\mathrm{Ni}^{\mathrm{II}} \mathbf{L}\right]$ towards $\mathrm{CO}_{2}$ binding would require a two-electron reduction and an optical promotion to the triplet state to activate the $\mathrm{Ni}^{\mathrm{I}}$ oxidation state. Otherwise, the $\pi$-conjugated (unsaturated) ligand remains the locus of the $\left[\mathbf{N i}^{\mathrm{II}} \mathbf{L}\right]$ reduction 
and the $\mathrm{Ni}^{\mathrm{II}}$ central atom shows no affinity forwards binding or reducing $\mathrm{CO}_{2}$. In the case of ${ }^{1}\left[\mathrm{Ni}^{\mathrm{II}} \mathbf{L H}\right]^{2+}$, the single electron reduction is already sufficient to reduce the central $\mathrm{Ni}^{\mathrm{II}}$ atom to $\mathrm{Ni}^{\mathrm{I}}$ and thus activate the affinity for bind and (partially) reduce $\mathrm{CO}_{2}$. A further reduction step of ${ }^{2}\left[\mathrm{Ni}^{\mathrm{I}} \mathbf{L H}\right]^{+}$leads to a considerably distorted geometry from the square planar one, with a $\mathrm{Ni}^{0}$ central atom, but the strong affinity forwards binding and reducing $\mathrm{CO}_{2}$ leads to a smaller distortion in ${ }^{1}\left[\mathbf{N i L H}-\mathrm{CO}_{2}\right]^{0}$ when compared to ${ }^{1}\left[\mathrm{Ni}^{0} \mathbf{L H}\right]^{0}$. Hence, after the first reduction step, $\left[\mathrm{Ni}^{\mathrm{I}} \mathbf{L H}\right]$ binds $\mathrm{CO}_{2}$ and is also able to accept one more electron with an electron transfer to the $\mathrm{CO}_{2}$ moiety and forming a stable ${ }^{1}\left[\mathrm{NiLH}-\mathrm{CO}_{2}\right]^{0}$ species, with the $\mathrm{CO}_{2}$ moiety experiencing the largest bend among the studied species. A further challenge to the possible working catalytic cycle of ${ }^{1}\left[\mathbf{N i L H}-\mathrm{CO}_{2}\right]^{0}$ is the split into $\left[\mathbf{N i}{ }^{\mathrm{I}} \mathbf{L H}\right]^{+}$ and $\mathrm{CO}_{2}{ }^{-}$species and/or to avoid the ${ }^{1}[\mathrm{NiLH}]^{0}$ species occurrence, which can be assumed to be unstable due to the considerable distortion of the coordination polyhedron.

Supplementary Materials: The following data are available online. Table S1: B3LYP/6-311G* energies/enthalpies. Table S2: bond distances $(\AA)$ and angles $\left(^{\circ}\right)$. Table S3: MPA charges. Table S4: QTAIM charges. Table S5: QTAIM BCP characteristics. Table S6: Mulliken populations of localized orbitals of complexes studied. Figure S1: comparison of chosen geometries. Figure S2 and Figure S3: frontier orbitals. SI_XYZ.zip contains the xyz geometries as separate files and XYZ_compounds.pdf contains the compounds' label, energy, enthalpy, and xyz file name.

Author Contributions: Conceptualization, B.V., M.Z., V.B.A. and L.B.; methodology, L.B.; formal analysis, B.V., M.Z., V.B.A. and L.B.; investigation, B.V., I.J., M.N. and L.B.; data curation, B.V., I.J., M.N. and L.B.; writing-original draft preparation, B.V., M.N. and L.B.; writing-review and editing, all authors; visualization, B.V.; supervision, J.K., P.R., M.Z., V.B.A. and L.B.; project administration, J.K., P.R., M.Z., V.B.A. and L.B.; funding acquisition, J.K., P.R., M.Z. and V.B.A. All authors have read and agreed to the published version of the manuscript.

Funding: This work received financial support from the Slovak Grant Agency APVV (contract Nos. APVV-15-0079, APVV-19-0024 and APVV-19-0087) and VEGA (contract Nos. 1/0718/19 and $1 / 0139 / 20$ ) and the Ministry of Education, Science, Research and Sport of the Slovak Republic by funds within the scheme "Excellent research teams". B.V. thanks the STU Grant scheme for further finances for the Support of Young Researchers (1859). MN thanks the Institution Development Program of the University of Ostrava for their financial support (IRP201826).

Institutional Review Board Statement: Not applicable.

Informed Consent Statement: Not applicable.

Data Availability Statement: Not applicable.

Acknowledgments: The HPC Centre at the Slovak University of Technology in Bratislava, which is a part of the Slovak Infrastructure of High-Performance Computing (SIVVP Project, ITMS code 262301200002, founded by the European Region Development Founds), is acknowledged for making computing facilities available.

Conflicts of Interest: The authors declare no conflict of interest.

\section{References}

1. Benson, E.E.; Kubiak, C.P.; Sathrum, A.J.; Smieja, J.M. Electrocatalytic and homogeneous approaches to conversion of $\mathrm{CO}_{2}$ to liquid fuels. Chem. Soc. Rev. 2009, 38, 89-99. [CrossRef]

2. Schneider, J.; Jia, H.; Muckerman, J.T.; Fujita, E. Thermodynamics and kinetics of $\mathrm{CO}_{2}, \mathrm{CO}$, and $\mathrm{H}^{+}$binding to the metal centre of $\mathrm{CO}_{2}$ reduction catalysts. Chem. Soc. Rev. 2012, 41, 2036-2051. [CrossRef]

3. Appel, A.M.; Bercaw, J.E.; Bocarsly, A.B.; Dobbek, H.; DuBois, D.L.; Dupuis, M.; Ferry, J.G.; Fujita, E.; Hille, R.; Kenis, P.J.A.; et al. Frontiers, Opportunities, and Challenges in Biochemical and Chemical Catalysis of $\mathrm{CO}_{2}$ Fixation. Chem. Rev. 2013, 113, 6621-6658. [CrossRef] [PubMed]

4. Bhugun, I.; Lexa, D.; Savéant, J.-M. Catalysis of the Electrochemical Reduction of Carbon Dioxide by Iron(0) Porphyrins: Synergystic Effect of Weak Brönsted Acids. J. Am. Chem. Soc. 1996, 118, 1769-1776. [CrossRef]

5. Wang, J.-W.; Liu, W.-J.; Zhong, D.-C.; Lu, T.-B. Nickel complexes as molecular catalysts for water splitting and $\mathrm{CO}_{2}$ reduction. Coord. Chem. Rev. 2019, 378, 237-261. [CrossRef]

6. Vogiatzis, K.D.; Polynski, M.V.; Kirkland, J.K.; Townsend, J.; Hashemi, A.; Liu, C.; Pidko, E.A. Computational Approach to Molecular Catalysis by 3d Transition Metals: Challenges and Opportunities. Chem. Rev. 2019, 119, 2453-2523. [CrossRef] 
7. Boutin, E.; Merakeb, L.; Ma, B.; Boudy, B.; Wang, M.; Bonin, J.; Anxolabéhère-Mallart, E.; Robert, M. Molecular catalysis of CO2 reduction: Recent advances and perspectives in electrochemical and light-driven processes with selected $\mathrm{Fe}, \mathrm{Ni}$ and $\mathrm{Co}$ aza macrocyclic and polypyridine complexes. Chem. Soc. Rev. 2020, 49, 5772-5809. [CrossRef] [PubMed]

8. Ishida, H.; Tanaka, K.; Tanaka, T. Electrochemical $\mathrm{CO}_{2}$ reduction catalyzed by ruthenium complexes $\left[\mathrm{Ru}(\mathrm{bpy})_{2}(\mathrm{CO})_{2}\right]^{2+}$ and $\left[\mathrm{Ru}(\mathrm{bpy})_{2}(\mathrm{CO}) \mathrm{Cl}\right]^{+}$. Effect of $\mathrm{pH}$ on the formation of $\mathrm{CO}$ and HCOO-. Organometallics 1987, 6, 181-186. [CrossRef]

9. Bruce, M.R.M.; Megehee, E.; Sullivan, B.P.; Thorp, H.; O'Toole, T.R.; Downard, A.; Meyer, T.J. Electrocatalytic reduction of carbon dioxide by associative activation. Organometallics 1988, 7, 238-240. [CrossRef]

10. Bolinger, C.M.; Story, N.; Sullivan, B.P.; Meyer, T.J. Electrocatalytic reduction of carbon dioxide by 2,2'-bipyridine complexes of rhodium and iridium. Inorg. Chem. 1988, 27, 4582-4587. [CrossRef]

11. Slater, S.; Wagenknecht, J.H. Electrochemical reduction of carbon dioxide catalyzed by $\mathrm{Rh}(\operatorname{diphos})_{2} \mathrm{Cl}$. J. Am. Chem. Soc. 1984, 106, 5367-5368. [CrossRef]

12. Raebiger, J.W.; Turner, J.W.; Noll, B.C.; Curtis, C.J.; Miedaner, A.; Cox, B.; DuBois, D.L. Electrochemical Reduction of CO 2 to CO Catalyzed by a Bimetallic Palladium Complex. Organometallics 2006, 25, 3345-3351. [CrossRef]

13. DuBois, D.L.; Miedaner, A.; Haltiwanger, R.C. Electrochemical reduction of carbon dioxide catalyzed by [Pd(triphosphine)(solvent)] $\left(\mathrm{BF}_{4}\right)_{2}$ complexes: Synthetic and mechanistic studies. J. Am. Chem. Soc. 1991, 113, 8753-8764. [CrossRef]

14. Dubois, D.L. Development of Transition Metal Phosphine Complexes as Electrocatalysts for $\mathrm{CO}_{2}$ and $\mathrm{CO}$ Reduction. Comments Inorg. Chem. 1997, 19, 307-325. [CrossRef]

15. Meshitsuka, S.; Ichikawa, M.; Tamaru, K. Electrocatalysis by metal phthalocyanines in the reduction of carbon dioxide. J. Chem. Soc. Chem. Commun. 1974, 158-159. [CrossRef]

16. Fisher, B.J.; Eisenberg, R. Electrocatalytic reduction of carbon dioxide by using macrocycles of nickel and cobalt. J. Am. Chem. Soc. 1980, 102, 7361-7363. [CrossRef]

17. Beley, M.; Collin, J.P.; Ruppert, R.; Sauvage, J.P. Electrocatalytic reduction of carbon dioxide by nickel cyclam ${ }^{2+}$ in water: Study of the factors affecting the efficiency and the selectivity of the process. J. Am. Chem. Soc. 1986, 108, 7461-7467. [CrossRef] [PubMed]

18. Balazs, G.B.; Anson, F.C. Effects of $\mathrm{CO}$ on the electrocatalytic activity of $\mathrm{Ni}$ (cyclam) ${ }^{2+}$ toward the reduction of $\mathrm{CO}_{2}$. J. Electroanal Chem. 1993, 361, 149-157. [CrossRef]

19. Hammouche, M.; Lexa, D.; Momenteau, M.; Saveant, J.M. Chemical catalysis of electrochemical reactions. Homogeneous catalysis of the electrochemical reduction of carbon dioxide by iron(" 0 ") porphyrins. Role of the addition of magnesium cations. J. Am. Chem. Soc. 1991, 113, 8455-8466. [CrossRef]

20. Grodkowski, J.; Neta, P.; Fujita, E.; Mahammed, A.; Simkhovich, L.; Gross, Z. Reduction of Cobalt and Iron Corroles and Catalyzed Reduction of $\mathrm{CO}_{2}$. J. Phys. Chem. A 2002, 106, 4772-4778. [CrossRef]

21. DeLaet, D.L.; Del Rosario, R.; Fanwick, P.E.; Kubiak, C.P. Carbon dioxide chemistry and electrochemistry of a binuclear cradle complex of nickel(0), $\mathrm{Ni}_{2}$ (.mu.-CNMe) $(\mathrm{CNMe})_{2}\left(\mathrm{PPh}_{2} \mathrm{CH}_{2} \mathrm{PPh}_{2}\right)_{2}$. J. Am. Chem. Soc. 1987, 109, 754-758. [CrossRef]

22. Simón-Manso, E.; Kubiak, C.P. Dinuclear Nickel Complexes as Catalysts for Electrochemical Reduction of Carbon Dioxide. Organometallics 2005, 24, 96-102. [CrossRef]

23. Wittrig, R.E.; Ferrence, G.M.; Washington, J.; Kubiak, C.P. Infrared spectroelectrochemical and electrochemical kinetics studies of the reaction of nickel cluster radicals $\left[\mathrm{Ni}_{3}(\mu 2-\mathrm{dppm})_{3}(\mu 3-\mathrm{L})(\mu 3 \mathrm{I})\right] \bullet\left(\mathrm{L}=\mathrm{CNR}, \mathrm{R}=\mathrm{CH}_{3}, \mathrm{i}-\mathrm{C}_{3} \mathrm{H}_{7}, \mathrm{C}_{6} \mathrm{H}_{11}, \mathrm{CH}_{2} \mathrm{C}_{6} \mathrm{H}_{5}, \mathrm{t}-\mathrm{C}_{4} \mathrm{H}_{9}\right.$, 2,6- $\mathrm{Me}_{2} \mathrm{C}_{6} \mathrm{H}_{3} ; \mathrm{L}=\mathrm{CO}$ ) with carbon dioxide. Inorg. Chim. Acta 1998, 270, 111-117. [CrossRef]

24. Ferrence, G.M.; Fanwick, P.E.; Kubiak, C.P. A telluride capped trinuclear nickel cluster $\left[\mathrm{Ni}_{3}\left(\mu 3-\mathrm{Te}_{2}\left(\mu-\mathrm{PPh}_{2} \mathrm{CH}_{2} \mathrm{PPh}_{2}\right)_{3}\right]^{+}\right.$with four accessible redox states $(\mathrm{n}=-1,0,1,2)$. Chem. Commun. 1996, 1575-1576. [CrossRef]

25. Haines, R.J.; Wittrig, R.E.; Kubiak, C.P. Electrocatalytic Reduction of Carbon Dioxide by the Binuclear Copper Complex [Cu 2 (6(diphenylphosphino-2,2'-bipyridyl $)_{2}\left(\mathrm{MeCN}_{2}\right]\left[\mathrm{PF}_{6}\right]_{2}$. Inorg. Chem. 1994, 33, 4723-4728. [CrossRef]

26. Morgenstern, D.A.; Ferrence, G.M.; Washington, J.; Henderson, J.I.; Rosenhein, L.; Heise, J.D.; Fanwick, P.E.; Kubiak, C.P. A Class of Halide-Supported Trinuclear Nickel Clusters $\left[\mathrm{Ni}_{3}(\mu 3-\mathrm{L})(\mu 3-\mathrm{X})(\mu 2-\mathrm{dppm})_{3}\right]^{\mathrm{n}+}(\mathrm{L}=\mathrm{I}-, \mathrm{Br}-, \mathrm{CO}, \mathrm{CNR} . ; \mathrm{X}=\mathrm{I}-, \mathrm{Br}-; \mathrm{n}=0,1$; $\mathrm{dppm}=\mathrm{Ph}_{2} \mathrm{PCH}_{2} \mathrm{PPh}_{2}$ ): Novel Physical Properties and the Fermi Resonance of Symmetric $\mu 3-\eta 1$ Bound Isocyanide Ligands. $J$. Am. Chem. Soc. 1996, 118, 2198-2207. [CrossRef]

27. Dražić, B.; Antonijević-Nikolić, M.; Žižak, Ž.; Tanasković, S. Synthesis and characterization of copper(II) octaazamacrocyclic complexes with glycine derivatives. In vitro antiproliferative and antimicrobial evaluation of the $\mathrm{Cu}$ (II) and Co(II) analogous. J. Serb. Chem. Soc. 2020, 85, 637-649. [CrossRef]

28. Antonijević-Nikolić, M.; Antić-Stanković, J.; Dražić, B.; Tanasković, S. New macrocyclic Cu(II) complex with bridge terephthalate: Synthesis, spectral properties, in vitro cytotoxic and antimicrobial activity. Comparison with related complexes. J. Mol. Struct. 2019, 1184, 41-48. [CrossRef]

29. Miodragović, Z.M.; Gordana, V.; Leovac, V.M. Tetranuclear Cu(II) complex with octaazamacrocycle and bridging bicyclic dicarboxylato ligands. J. Serb. Chem. Soc. 2001, 66, 597-603. [CrossRef]

30. Tanasković, S.; Antonijević-Nikolić, M.; Hollo, B.B.; Dražić, B.; Stanojković, T.; Meszaros-Szecsenyi, K.; Vucković, G. Correlations between the in vitro antiproliferative activity, structure and thermal stability of some macrocyclic dinuclear $\mathrm{Cu}$ (II) complexes. J. Serb. Chem. Soc. 2014, 79, 1235-1247. [CrossRef]

31. Antonijević-Nikolić, M.; Antić-Stanković, J.; Tanasković, S.B.; Korabik, M.J.; Gojgić-Cvijović, G.; Vučković, G. Preparation, characterisation and study of in vitro biologically active azamacrocyclic $\mathrm{Cu}$ (II) dicarboxylate complexes. J. Mol. Struct. 2013, 1054-1055, 297-306. [CrossRef] 
32. Beley, M.; Collin, J.-P.; Ruppert, R.; Sauvage, J.-P. Nickel(II)-cyclam: An extremely selective electrocatalyst for reduction of $\mathrm{CO}_{2}$ in water. J. Chem. Soc. Chem. Commun. 1984, 1315-1316. [CrossRef]

33. Collin, J.P.; Jouaiti, A.; Sauvage, J.P. Electrocatalytic properties of (tetraazacyclotetradecane)nickel $(2+)$ and $\mathrm{Ni}_{2}\left(\mathrm{biscyclam}^{4+}\right.$ with $^{4}$ respect to carbon dioxide and water reduction. Inorg. Chem. 1988, 27, 1986-1990. [CrossRef]

34. Savéant, J.-M. Molecular Catalysis of Electrochemical Reactions. Mechanistic Aspects. Chem. Rev. 2008, 108, 2348-2378. [CrossRef] [PubMed]

35. Schmidt, M.H.; Miskelly, G.M.; Lewis, N.S. Effects of redox potential, steric configuration, solvent, and alkali metal cations on the binding of carbon dioxide to cobalt(I) and nickel(I) macrocycles. J. Am. Chem. Soc. 1990, 112, 3420-3426. [CrossRef]

36. Fujita, E.; Creutz, C.; Sutin, N.; Szalda, D.J. Carbon dioxide activation by cobalt(I) macrocycles: Factors affecting carbon dioxide and carbon monoxide binding. J. Am. Chem. Soc. 1991, 113, 343-353. [CrossRef]

37. Rudolph, M.; Dautz, S.; Jäger, E.-G. Macrocyclic [N42-] Coordinated Nickel Complexes as Catalysts for the Formation of Oxalate by Electrochemical Reduction of Carbon Dioxide. J. Am. Chem. Soc. 2000, 122, 10821-10830. [CrossRef]

38. Fujita, E.; Szalda, D.J.; Creutz, C.; Sutin, N. Carbon dioxide activation: Thermodynamics of carbon dioxide binding and the involvement of two cobalt centers in the reduction of carbon dioxide by a cobalt(I) macrocycle. J. Am. Chem. Soc. 1988, 110, 4870-4871. [CrossRef]

39. Ogata, T.; Yanagida, S.; Brunschwig, B.S.; Fujita, E. Mechanistic and Kinetic Studies of Cobalt Macrocycles in a Photochemical $\mathrm{CO}_{2}$ Reduction System: Evidence of Co- $\mathrm{CO}_{2}$ Adducts as Intermediates. J. Am. Chem. Soc. 1995, 117, 6708-6716. [CrossRef]

40. Creutz, C.; Schwarz, H.A.; Wishart, J.F.; Fujita, E.; Sutin, N. Thermodynamics and kinetics of carbon dioxide binding to two stereoisomers of a cobalt(I) macrocycle in aqueous solution. J. Am. Chem. Soc. 1991, 113, 3361-3371. [CrossRef]

41. Fujita, E.; Creutz, C.; Sutin, N.; Brunschwig, B.S. Carbon dioxide activation by cobalt macrocycles: Evidence of hydrogen bonding between bound $\mathrm{CO}_{2}$ and the macrocycle in solution. Inorg. Chem. 1993, 32, 2657-2662. [CrossRef]

42. Fujita, E.; Furenlid, L.R.; Renner, M.W. Direct XANES Evidence for Charge Transfer in Co-CO $\mathrm{C}_{2}$ Complexes. J. Am. Chem. Soc. 1997, 119, 4549-4550. [CrossRef]

43. Fujita, E.; van Eldik, R. Effect of Pressure on the Reversible Binding of Acetonitrile to the "Co(I) $-\mathrm{CO}_{2}$ " Adduct To Form Cobalt(III) Carboxylate. Inorg. Chem. 1998, 37, 360-362. [CrossRef]

44. Kelly, C.A.; Mulazzani, Q.G.; Blinn, E.L.; Rodgers, M.A.J. Kinetics of CO Addition to Ni(cyclam) ${ }^{+}$in Aqueous Solution. Inorg. Chem. 1996, 35, 5122-5126. [CrossRef]

45. Kelly, C.A.; Blinn, E.L.; Camaioni, N.; D’Angelantonio, M.; Mulazzani, Q.G. Mechanism of $\mathrm{CO}_{2}$ and $\mathrm{H}^{+}$Reduction by Ni(cyclam) ${ }^{+}$ in Aqueous Solution. A Pulse and Continuous Radiolysis Study. Inorg. Chem. 1999, 38, 1579-1584. [CrossRef]

46. Fujita, E.; Haff, J.; Sanzenbacher, R.; Elias, H. High Electrocatalytic Activity of RRSS-[NiIIHTIM] $\left(\mathrm{ClO}_{4}\right)_{2}$ and $[\mathrm{NiIIDMC}]\left(\mathrm{ClO}_{4}\right)_{2}$ for Carbon Dioxide Reduction (HTIM = 2,3,9,10-Tetramethyl-1,4,8,11-tetraazacyclotetradecane, DMC = C-meso-5,12-Dimethyl1,4,8,11-tetraazacyclotetradecane). Inorg. Chem. 1994, 33, 4627-4628. [CrossRef]

47. Gagne, R.R.; Ingle, D.M. One-electron-reduced nickel(II)-macrocyclic ligand complexes. Four-coordinate nickel(I) species and nickel(II)-ligand radical species which form paramagnetic, five-coordinate nickel(I) adducts. Inorg. Chem. 1981, $20,420-425$. [CrossRef]

48. Furenlid, L.R.; Renner, M.W.; Szalda, D.J.; Fujita, E. EXAFS studies of nickel(II), nickel(I), and Ni(I)-CO tetraazamacrocycles and the crystal structure of $(5,7,7,12,14,14$-hexamethyl-1,4,8,11-tetraazacyclotetradeca-4,11-diene)nickel(I) perchlorate. J. Am. Chem. Soc. 1991, 113, 883-892. [CrossRef]

49. Froehlich, J.D.; Kubiak, C.P. Homogeneous $\mathrm{CO}_{2}$ reduction by $\mathrm{Ni}($ cyclam) at a glassy carbon electrode. Inorg. Chem. 2012, 51, 3932-3934. [CrossRef]

50. Sakaki, S. An ab initio MO/SD-CI study of model complexes of intermediates in electrochemical reduction of carbon dioxide catalyzed by $\mathrm{NiCl}_{2}$ (cyclam). J. Am. Chem. Soc. 1992, 114, 2055-2062. [CrossRef]

51. Sakaki, S. Can carbon dioxide coordinate to a nickel(I) complex? An ab initio MO/SD-CI study. J. Am. Chem. Soc. 1990, 112, 7813-7814. [CrossRef]

52. Dobrov, A.; Darvasiová, D.; Zalibera, M.; Bučinský, L.; Puškárová, I.; Rapta, P.; Shova, S.; Dumitrescu, D.; Martins, L.M.D.R.S.; Pombeiro, A.J.L.; et al. Nickel(II) Complexes with Redox Noninnocent Octaazamacrocycles as Catalysts in Oxidation Reactions. Inorg. Chem. 2019, 58, 11133-11145. [CrossRef] [PubMed]

53. Darvasiová, D.; Šoral, M.; Puškárová, I.; Dvoranová, D.; Vénosová, B.; Bučinský, L.; Zalibera, M.; Dujnič, V.; Dobrov, A.; Schwalbe, M.; et al. Spectroelectrochemical, photochemical and theoretical study of octaazamacrocyclic nickel(II) complexes exhibiting unusual solvent-dependent deprotonation of methylene group. Electrochim. Acta 2019, 326. [CrossRef]

54. Kimura, E.; Wada, S.; Shionoya, M.; Okazaki, Y. New Series of Multifunctionalized Nickel(II)-Cyclam (Cyclam = 1,4,8,11Tetraazacyclotetradecane) Complexes. Application to the Photoreduction of Carbon Dioxide. Inorg. Chem. 1994, 33, 770-778. [CrossRef]

55. Song, J.; Klein, E.L.; Neese, F.; Ye, S. The Mechanism of Homogeneous $\mathrm{CO}_{2}$ Reduction by Ni(cyclam): Product Selectivity, Concerted Proton-Electron Transfer and C-O Bond Cleavage. Inorg. Chem. 2014, 53, 7500-7507. [CrossRef]

56. Wu, Y.; Rudshteyn, B.; Zhanaidarova, A.; Froehlich, J.D.; Ding, W.; Kubiak, C.P.; Batista, V.S. Electrode-Ligand Interactions Dramatically Enhance $\mathrm{CO}_{2}$ Conversion to $\mathrm{CO}$ by the [Ni(cyclam)] $\left(\mathrm{PF}_{6}\right)_{2}$ Catalyst. ACS Catal. 2017, 7, 5282-5288. [CrossRef]

57. Frisch, M.J.; Schlegel, H.B.; Scuseria, G.E.; Robb, M.A.; Cheeseman, J.R.; Scalmani, G.; Barone, V.; Petersson, G.A.; Nakatsuji, H.; Li, X.; et al. Gaussian 16, Revision B.01; Gaussian, Inc.: Wallingford, CT, USA, 2016. 
58. Lee, C.; Yang, W.; Parr, R. Development of the Colle- Salvetti correlation energy formula into a functional of the electron density. Phys. Rev. B 1988, 37, 785-789. [CrossRef]

59. Becke, A.D. Density Functional Thermochemistry III The Role of Exact Exchange. J. Chem. Phys. 1993, 98, 5648-5652. [CrossRef]

60. Stephens, P.J.; Devlin, F.J.; Chabalowski, C.F.; Frisch, M.J. Ab Initio Calculation of Vibrational Absorption and Circular Dichroism Spectra Using Density Functional Force Fields. J. Phys. Chem. 1994, 98, 11623-11627. [CrossRef]

61. Vosko, S.H.; Wilk, L.; Nusair, M. Accurate spin-dependent electron liquid correlation energies for local spin density calculations: A critical analysis. Can. J. Phys. 1980, 58, 1200-1211. [CrossRef]

62. Krishnan, R.; Binkley, J.S.; Seeger, R.; Pople, J.A. Self-Consistent Molecular-Orbital Methods. XX. Basis Set for Correlated Wave-Functions. J. Chem. Phys. 1980, 72, 650-654. [CrossRef]

63. McLean, A.D.; Chandler, G.S. Contracted Gaussian-basis sets for molecular calculations. 1. 2nd row atoms, Z = 11-18. J. Chem. Phys. 1980, 72, 5639-5648. [CrossRef]

64. Wachters, A.J.H. Wavefunctions Containing Third-Row Atoms. J. Chem. Phys. 1970, 52, 1033-1036. [CrossRef]

65. Cossi, M.; Barone, V.; Mennucci, B.; Tomasi, J. Ab initio study of ionic solutions by a polarizable continuum dielectric model. Chem. Phys. Lett. 1998, 286, 253-260. [CrossRef]

66. Cossi, M.; Barone, V.; Cammi, R.; Tomasi, J. Ab initio study of solvated molecules: A new implementation of the polarizable continuum model. Chem. Phys. Lett. 1996, 255, 327-335. [CrossRef]

67. Boys, S.F.; Bernardi, F. The calculation of small molecular interactions by the differences of separate total energies. Some procedures with reduced errors. Mol. Phys. 1970, 19, 553-566. [CrossRef]

68. Simon, S.; Duran, M.; Dannenberg, J.J. How does basis set superposition error change the potential surfaces for hydrogen-bonded dimers? J. Chem. Phys. 1996, 105, 11024-11031. [CrossRef]

69. Baranov, A.I.; Ponec, R.; Kohout, M. Domain-averaged Fermi-hole analysis for solids. J. Chem. Phys. 2012, 137, 214109. [CrossRef]

70. Ponec, R.; Duben, A.J. Electron pairing and chemical bonds: Bonding in hypervalent molecules from analysis of Fermi holes. J. Comput. Chem. 1999, 20, 760-771. [CrossRef]

71. Cooper, D.L.; Ponec, R. Bond formation in diatomic transition metal hydrides: Insights from the analysis of domain-averaged fermi holes. Int. J. Quant. Chem. 2013, 113, 102-111. [CrossRef]

72. Kohout, M. DGrid; Version 5.1; Max-Plack-Institut für Chemische Physik fester Stoffe: Dresden, Germany, 2019.

73. Neese, F. The ORCA program system. Wiley Interdiscip. Rev. Comput. Mol. Sci. 2012, 2, 73-78. [CrossRef]

74. Bader, R.F.W. Atoms in Molecules: A Quantum Theory; Oxford University Press: Oxford, UK, 1990 ; ISBN 0198558651.

75. Keith, T.A. AIMAll; Version 19.10.12; TK Gristmill Software: Overland Park, KS, USA, 2019. Available online: http://aim. tkgristmill.com (accessed on 3 June 2021).

76. Varetto, U. Molekel, Version 5.4. Available online: https://ugovaretto.github.io/molekel/wiki/pmwiki.php/Main/ DownloadBinary.html (accessed on 3 June 2021). 